\title{
DIE ONTWIKKELING VAN 'N MILITÊRE INLIGTINGSVERMOË VIR DIE UNIEVERDEDIGINGSMAG, 1937-1943
}

\author{
Lt M.C. van Deventer \\ Departement Krygsgeskiedenis, Militêre Akademie
}

\begin{abstract}
Upon the establishment of the Union Defence Force in 1912, no provision was made for a military intelligence capability. During the First World War various so-called intelligence units were raised and a Military Intelligence function was established within the General Staff section. After the war, this function went into gradual decline. By 1937, a renewed interest in intelligence resulted in the part-time appointment of Lieutenant Colonel B.W.Thwaites as head of Military Intelligence.
\end{abstract}

\begin{abstract}
After the declaration of war in 1939, Military Intelligence experienced a rapid growth. Intelligence officers were trained as such and agents were recruited. The Military Intelligence organization was divided into two upon the appointment of a Director Intelligence (Civilian Security) and a Deputy Director Military Intelligence. After initial organizational problems, an Intelligence Clearance Bureau was established. The Intelligence Directorate was disbanded and only the Military Intelligence Sub-directorate continued to exist. An Intelligence Corps was developed for the Mobile Field Force (MFF), from a "shadow structure" named Section Ix within Military Intelligence. In 1943, Military Intelligence was upgraded to a full directorate and was responsible for information, intelligence, security and censorship.
\end{abstract}

\section{INLEIDING}

\section{AGTERGROND}

Suid-Afrika het op Maandag 4 September 1939, na ' $n$ historiese debat in die Parlement, besluit om teen Duitsland oorlog te verklaar. Die mosie is met 80 stemme teen 67 goedgekeur. Die skrale meerderheid het gedui op ' $n$ diep verdeelde land met veral die Afrikaanssprekende gemeenskap wat sterk gekant was teen deelname aan die oorlog. Die Unieverdedigingsmagte (UVM), met ' $n$ Staande Mag van 4500 man en 313 offisiere, was ook onvoorbereid vir 'n oorlog.'

Teen só ' $n$ agtergrond sou dit verstaanbaar gewees het, indien die UVM se inligtingsvermoë bloot latent was. Tsjeggo-Slowakye, in die brandpunt van die dreigende oorlogswolke, het in 1934 hulle militêre inligtingsvermoë begin voorberei op ' $n$ moontlike oorlog. ${ }^{2}$ Brittanje het eers in 1935 voorbereidings begin tref. ${ }^{3}$ Suid-Afrika was nog meer verwyderd van enige bedreiging. Die UVM sou dus min motivering gehad het om te investeer in ' $n$ faset van oorlogvoering wat tradisioneel in ' $n$ vredestydse weermag beskou word as ' $n$ "minderwaardige roeping" of "benede die status van professionele soldate". ${ }^{4}$ Indien dit die geval was, sou die UVM ernstige probleme tydens die oorlog beleef het.

Die mate waarin die UVM hierdie probleem vermy en vroegtydig opgelos het, sou 'n goeie aanduiding wees van die paraatheid van die UVM. Die UVM sou noodwendig sy inligtingsvermoë moes ontwikkel om aan die normale behoeftes van ' $n$ weermag te voldoen. ' $n$ Effektiewe inligtingsvermoë is immers fundamenteel belangrik vir die beplanning en uitvoering van operasies. ${ }^{5}$

'n Studie van die ontwikkelingsproses van die UVM se militêre inligtingsvermoë is om verskeie redes belangrik. Baie min historiese werke oor militêre inligting in dié periode, is beskikbaar. Die verdeelde aard van die Suid-Afrikaanse samelewing sou ook ' $n$ besondere karakter aan die inligtingsdiens gegee het. Dié studie sal verder lig werp op die problematiek (bedreiging vir effektiwiteit) rondom die skep

J. Crwys-Williams : A Country at War, 1939-1945; The Mood of a Nation (Rivonia 1992), pp.16-21.

F. Moravec : Master of Spies (London 1981), pp.19-25.

F.H. Hinsley: British Intelligence in the Second World War (London 1979), pp.10-12.

F. Moravec: Master of Spies, p.2.

S.C. le Grange : 'Die Geskiedenis van Hoof van Staf Inligting', Militaria 12(2) 1982, pp.56-58. 
van 'n militêre inligtingsvermoë, ná 'n periode van afskeping.

\section{DOEL}

Die doel van die geskrif is om die daarstel van die UVM se militêre inligtingsvermoë gedurende 1937 tot 1943 te ontleed, ten einde te bepaal of dit aan die vereistes van ' $n$ effektiewe inligtingsdiens voldoen het.

\section{BESTEK}

Die ontwikkelingsproses word ontleed aan die hand van vyf indelings. Eerstens word daar gefokus op die vooroorlogse periode (1912-1939) met ' $n$ breë oorsig oor die Suid-Afrikaanse militêre inligting gedurende dié tydperk, wat deur ' $n$ bespreking van It kol B.W. Thwaites se hervorminge voor die oorlog gevolg word. Tweedens word die breë ontwikkeling en herorganisasie van Militêre Inligting tydens die oorlog ontleed aan die hand van die periode 1939 tot Oktober 1940, die herorganisasie in Oktober 1940 en die inligtingskomponent van die sogenaamde "Mobile Frontier Force" (MMF). Die werking van Militêre Inligting se drie subseksies word daarna bespreek. Vierdens word die komponente van die UVM se militêre inligtingsvermoë (Inligtingskorps, Veldsekerheidspolisie (VSP), luginligtingskakeloffisiere (AILO), die radio-onderskeppingseenheid en die opvoedingsoffisiere) behandel. Vyfdens word die aandag gevestig op enkele produkte van Militêre Inligting as ' $n$ aanduiding van die effektiwiteit van die organisasie.

Militêre Inligting word gedefinieer as die organisasie en strukture wat aan die UVM se inligtingsbehoeftes moes voorsien. Lugmag- en Vlootinligting val grotendeels buite die bestek van dié studie. Die UVMfilmeenheid en die Historiese Rekordafdeling, wat organisatories deel van Militêre Inligting was, word ook nie behandel nie, omdat dit nie deel van Militêre Inligting se lynfunksie was nie. Radio-onderskepping, wat organisatories nie deel van Militêre Inligting was nie, word wel behandel omdat dit ' $n$ belangrike insamelingsmiddel was.

Die definiëring van effektiwiteit is meer problematies. Kol W.V. Kennedy beklemtoon sekerheid en teeninligting as groot bedreigings vir ' $n$ inligtingsorganisasie se effektiwiteit. ${ }^{6}$ Ander skrywers waar- sku weer teen verpolitisering. ${ }^{7}$ Die bereiking van doelwitte is nie ' $n$ bruikbare maatstaf nie, omdat hulle selde beskikbaar was (of eksplisiet gestel is). Vir dié studie sal effektiwiteit kwalitatief gemeet word deur die aanduiding van sterk en swak punte wat effektiwiteit kan beïnvloed. Daar word aanvaar dat daar breë ooreenkomste tussen die Britse en UVMinligtingspraktyke was.

Die dokumentasie van die geskiedenis van ' $n$ moderne inligtingsorganisasie is altyd problematies. Sensitiewe aspekte word nie gedokumenteer nie, of die dokumente word na gebruik vernietig. ${ }^{8}$ Die UVM se militêre inligting is geen uitsondering nie. Groot hoeveelhede dokumentasie is deur die Smuts-regering voor 1948 vernietig..$^{9}$ Dié vernietiging het min informasie oor Militêre Inligting nagelaat. Baie van die oorblywende informasie is klaarblyklik nog geklassifiseer. Genoeg informasie bestaan egter om ' $n$ realistiese beeld van Militêre Inligting weer te gee.

\section{DIE VOOROORLOGSE PERIODE 1912-1939}

\section{MILITÊRE INLIGTING IN SUID- AFRIKA 1912-1936}

Ondervinding tydens die Tweede Anglo-Boereoorlog het Brittanje genoodsaak om sy militêre inligtingsvermoë uit te brei en te verbeter. ${ }^{10}$ Dié lesse is nie aan die UVM oorgedra nie. Geen voorsiening vir inligting is gemaak in die UVM se organisasie in 1912 nie. Die rede hiervoor was klaarblyklik dat die Staande Mag slegs verantwoordelik was vir opleiding en binnelandse beveiliging, terwyl die Britse garnisoen self ' $n$ goeie inligtingsorganisasie gehad het. ${ }^{11}$

In die gespanne periode voor die uitbreek van die Eerste Wêreldoorlog, is verskeie Burgermag-inligtingseenhede (byvoorbeeld die 4de Informasie Eenheid en die "Transvaal Intelligence Corps") gemobiliseer. ${ }^{12}$ Hierdie eenhede was egter hoofsaaklik verantwoordelik vir berede insameling (met ander woorde tradisionele verkenners). Die sterkte van so ' $n$ eenheid was byvoorbeeld 50 man onder bevel van ' $n$ majoor. Lt kol P.C.B. Skinner is wel later aangestel as Afdelingshoof van Inligting, Hoof van die Generale Staf. ${ }^{13}$ Staatsamptenare is van ander de-

\footnotetext{
W.V. Kennedy: The Intelligence War (Roggebaai 1983), pp.14-19.

R.K. Betts : 'Policy-makers and Intelligence Analysts: Love, Hate or Indifference?', Intelligence and National Security 3(1) Jan 1988, pp.184-189.

T.G. Ferguson : British Military Intelligence, 1890-1914 (London 1984), p.xxi.

I.J. van der Waag : 'Military Record Preservation in South Africa, 1914-1992', Militaria 23(4) 1993, pp.23-25.

T.G. Ferguson: British Military Intelligence, 1870-1914, p.233.

11 Militêre Argiefbewaarplek, Pretoria (hierna MAB) : argief van die Stafoffisier, Militêr-Historiese en Argivale Dienste (hierna MHAD), deel 1 (ontbinde eenhede), Suid-Afrikaanse Inligtingskorps, p.1.

12 Ibid, p.4.

13 S.C. le Grange : Die Geskiedenis van Hoof van Staf Inligting, Militaria 12(2) 1982, pp.56-57.
} 
partemente afgedeel om in dié afdeling te werk. Inligtingsvermoëns is alleenlik aan magte te velde toegevoeg indien hulle nie van Britse inligtingstrukture gebruik kon maak nie, soos byvoorbeeld gedurende die Duits-Suidwes-Afrika-veldtog. ${ }^{14}$

Eers teen 1917 was die inligtingsfunksie formeel deel van die Generale Staf, toe ' $n$ afdeling Gll verantwoordelik gemaak is vir inligting in die UVM. Na die oorlog het slegs 'n vaag omlynde inligtingsfunksie onder die Adjunkhoof van die Generale Staf geresorteer. ${ }^{15}$ Teen 1921 was daar 'n hoog aangeskrewe vlootinligtingstaf in Kaapstad wat klaarblyklik verantwoordelik was vir die meeste buitelandse inligting wat die UVM ontvang het. ${ }^{16}$ Volgens 'n organigram, gedateer 25 Oktober 1928, was die Gll-afdeling op dié stadium verantwoordelik vir inligting (tesame met stafpligte by die vloot en lugmag, seindiens en andere). ${ }^{17}$ Die Hoof van die Generale Staf (HGS), generaal A.J.E. Brink, was primêr besorg oor inligting uit die swart protektorate en die beperkte vermoëns was dan ook so gefokus. ${ }^{18}$

Die grootste beperking op inligting was fondse. Dit het meegebring dat ' $n$ sentrale inligtingskoördineringsliggaam nie gevestig kon word nie. Daar was gevolglik min interdepartementele samewerking. ${ }^{19}$ Die posisie van die militêre inligtingstaf het ook nie verbeter nie. In 1933 was dit een van vier funksies wat onder die GSO1-pos (Generale Staf Offisier 1) geresorteer het. ${ }^{20}$ Teen 1935 is inligting onder die beheer van die Direkteur van Krygsverrigtinge en Oefeninge geplaas, maar dit was nou een van agt funksies van die ASO111 (Tweede-luitenant Van Jaarsveld). In Oktober 1935 het Italië Abessinië binnegeval. Dit sou die oorlogswolke nader aan SuidAfrika waai en ' $n$ hernude belangstelling in inligting aangewakker. ${ }^{21}$

\section{KOLONEL B.W. THWAITES WORD HOOF VAN MILITÊRE INLIGTING}

Lt kol Bartie Wilken Thwaites is vroeg in 1937 aangestel as Adjunk-direkteur Militêre Inligting (ADMI) met die opdrag om ' $n$ inligtingsvermoë te vestig. Sy vorige aanstelling was bevelvoerder "Imperial Light Horse", 'n Burgermag-eenheid. ${ }^{22}$ Dit is nie dui-

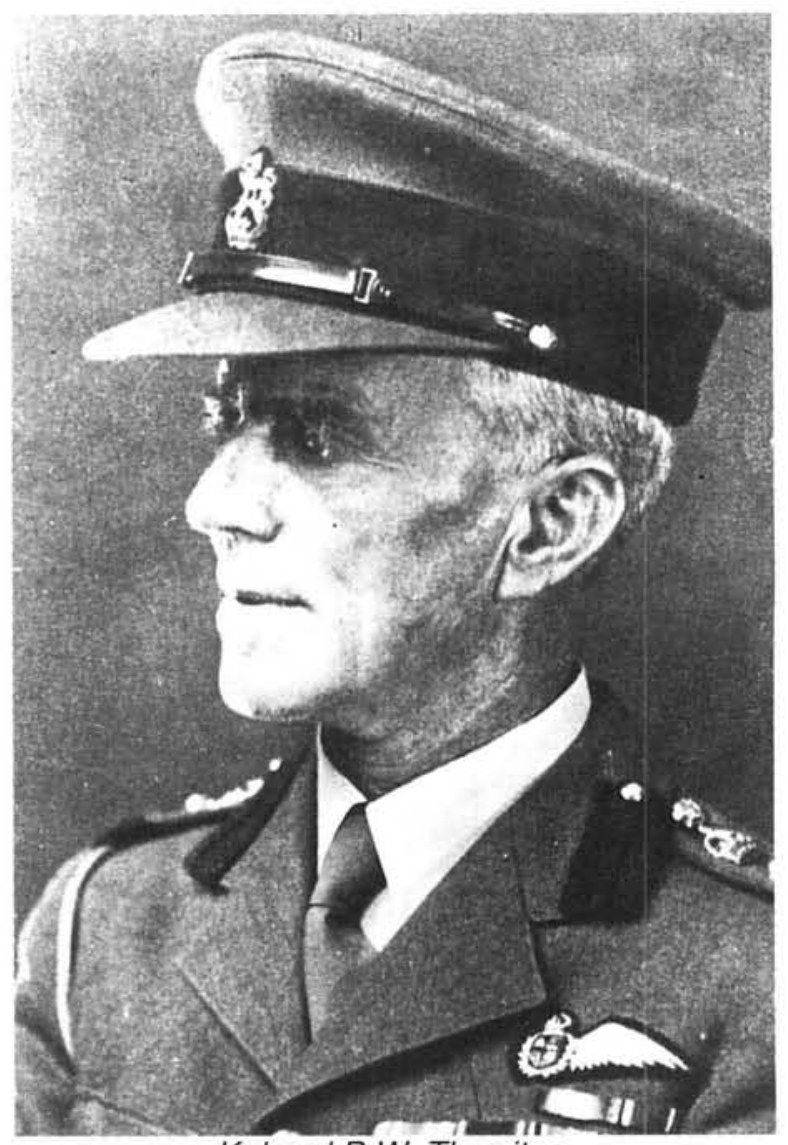

Kolonel B.W. Thwaites.

delik waarom spesifiek hy gekies is nie. (Hy was reeds 57 jaar oud in 1937 en sy aanstelling is elke jaar verleng. $)^{23}$ Lt kol Thwaites se burgerlike beroep was wel dié van assistent-redakteur van die Star. ${ }^{24}$ 'n Joernalistieke agtergrond kon dus ' $n$ aanbeveling vir die werk gewees het. Die aanstelling was klaarblyklik die resultaat van 'n lang debat tussen die HGS en die Sekretaris van Verdediging. ${ }^{25}$ Lt kol Thwaites moes dus oor eienskappe beskik het wat hom spesifiek vir dié werk geskik gemaak het.

Oor It kol Thwaites as persoon is min informasie bekend. Benewens sy memorandum vir die UVM se Historiese Afdeling (voltooi in 1945), ${ }^{26}$ het hy min geskrewe werk agtergelaat. Hy het die hoof van Militêre Inligting gebly tot November 1940 , toe hy die bevelvoerder van Kommandement Witwatersrand geword het. Dié pos is opgevolg met 'n aanstelling as die bevelvoerder van 9 Infanterie Brigade,

\footnotetext{
MAB : MHAD, deel 1 (ontbinde eenhede), Suid-Afrikaanse Inligtingskorps, pp.5-7.

Ibid, p.8.

16 MAB : argief van die Hoof van die Generale Staf (hierna CGS) Groep 2, houer 42, lêer 52426, Brief aan die Kommissaris, Doeane en Aksyn, 6 Des 1921.

MAB: Pamfletversameling, houer 99, no 3111, Voorgeskiedenis van die Direkteur-generaal van die Landmag.

18 MAB: MHAD, deel 1 (ontbinde eenhede), Suid-Afrikaanse Inligtingskorps, pp.10-11.

19 Ibid, pp.11-12.

MAB : Pamfletversameling, houer 99, no 3111, Voorgeskiedenis van die Direkteur-generaal van die Landmag.

Ibid, p.4.

MAB : Personeelargief en Reserwes (hierna PAR), lêer P1/3653, Lt kol Bartie Wilken Thwaites.

MAB : PAR, lêer P1/3653, Brief aan die Minister van Verdediging, ongedateerd.

MAB : Narratives and Unfo, $24: 14461-14650$, pp.14612-14613.

Ibid, p.14613,

Ibid, p.14535.
} 
Piet Retief (April 1941). ${ }^{27}$ Daar was hy betrokke by die beplanning van ' $n$ inval in Mosambiek, wat nooit gerealiseer het nie (Z-plan). ${ }^{28} \mathrm{Kol}$ Thwaites het sy loopbaan afgesluit met ' $n$ pos as assistent tot die HGS, waarna hy afgetree het. ${ }^{29}$

Lt kol Thwaites se aanstelling in die UVM was op ' $n$ deeltydse grondslag, met die gevolg dat hy sy weeklikse halfdag verlof by die Stargegroepeer het, sodat hy elke twee weke een dag aan sy inligtingswerk kon bestee. Hy het sonder agtergrondkennis en sonder enige voorbereidende werk in 'n pos ingestap. Hy kon ook geen teken van inligtingswerk vind wat reeds gedoen was nie. Die enigste beskikbare materiaal was weeklikse inligtingsopsommings van die Britse "War Office" en "Admiralty". Geen inligting was beskikbaar oor vyandelike gebiede in Afrika nie en daar was geen skakeling met die Britse gebiede nie. Lt kol Thwaites moes dus die werk leer ken en terselfdertyd ' $n$ hele inligtingsorganisasie vestig. $^{30}$

Kort na sy aanstelling is It kol Thwaites die geleentheid gegun om 14 dae by die "War Office" vir opleidingsdoeleindes deur te bring. ${ }^{31}$ Hy moes die organisering en koördinering van militêre inligting by die Britse afdelings $\mathrm{MI} 1$, MI 3 en MI 5 bestudeer. Hy is afgedeel na die Britse 6 Infanterie Brigade vir die duur van die opleiding, met die verstandhouding dat dit die Britse belastingbetaler nie ' $n$ pennie sou kos nie! ${ }^{32}$ Die tyd was egter baie kort en die Britte was ook nie gretig om sensitiewe inligting te deel nie, klaarblyklik omdat hulle nie die destydse Hertzog-regering en die Suid-Afrikaanse Polisie vertrou het nie. ${ }^{33} \mathrm{Lt}$ kol Thwaites het met sy terugkoms in September 1937 ' $n$ verslag aan kol P. de Waal (Direkteur Operasies en Inligting) voorgelê. ${ }^{34}$

In sy verslag het It kol Thwaites gepleit dat die Britse werksdokument Conduct of Work as model vir die UVM se inligtingsorganisasie aanvaar moes word. Hy het intussen gereël dat die "War Office" inligting oor die Afrika-gebied met die UVM uitruil. Skakeling is ook bewerkstellig tussen die Departement van Verdediging, die Suid-Afrikaanse Polisie en die Departement van Buitelandse Sake. Die insameling van informasie met gebrekkige fonse was meer problematies. Vrywillige korrespondente (agente) het wel informasie verskaf oor Nazi-aktiwiteite in Suidwes-Afrika en selfs verder noord. ${ }^{35}$ Dié tipe informasie is natuurlik nie altyd betroubaar nie en sulke agente kon nie op spesifieke teikens gerig word nie.

Teen Oktober 1938 het It kol Thwaites ' $n$ tweede verslag, "Intelligence - interim report on organisation in peace" aan kol George Brink, Direkteur Opleiding en Operasies, voorgelê. ' $n$ Vredestydse organisasie met minstens twee Burgermag-offisiere en ' $n$ klerk is voorgestel. Hegter sekerheidskakeling moes met ander departemente verkry word en ' $n$ vrywillige inligtingskorps moes op die been gebring word. Weens politieke en ekonomiese redes is die voorstelle slegs gedeeltelik uitgevoer. ' $n$ Lêerstelsel en databank is wel ontwikkel en inligtingstawwe is by baie formasies en eenhede gevestig (klaarblyklik aanstellings uit die eenhede self). Twee offisiere, kapteins A.L. Chapman en H.J. Steyn, is ook tot die Militêre Inligtingafdeling toegevoeg. Lt kol Thwaites se voorstel in April 1939 dat die Militêre Inligtingafdeling op ' $n$ oorlogsgrondslag gebring moes word (volgens die Britse handleiding Manual of Military Intelligence in the Field) is geïgnoreer. ${ }^{36}$ Die UVM het dus die Tweede Wêreldoorlog met ' $n$ Militêre Inligtingstaf van drie offisiere betreë.

\section{OORLOGTYDSE ONTWIKKELING EN HERORGANISASIE}

\section{DIE PERIODE SEPTEMBER 1939 TOT OKTOBER 1940}

Die Militêre Inligtingafdeling is na die uitbreek van die oorlog op 3 September 1939 op ' $n$ oorlogsgrondslag geplaas. Dit het bestaan uit vier offisiere: It kol B.W. Thwaites, Adjunkdirekteur Militêre Inligting (ADMI), maj J. McGarel Groves, kapt A.L. Chapman en kapt G. Makepeace. Kapt Steyn het sy ontslag aangevra (moontlik weens politieke oortuigings).

Die afdeling is oorval met werksaanbiedinge en informasie oor "subversiewe aktiwiteite". Die eerste taak was egter om inligtingsoffisiere vir ' $n$ moontlike inligtingskorps opgelei te kry. Met dié doel voor oë is ' $n$ reeks kursusse by die Militêre Kollege onder leiding van maj J. Kreft en kapt C. Powell gereël. ${ }^{37}$

Lt kol Thwaites se groot probleem op die stadium was finansies. Op 15 September is magtiging verkry

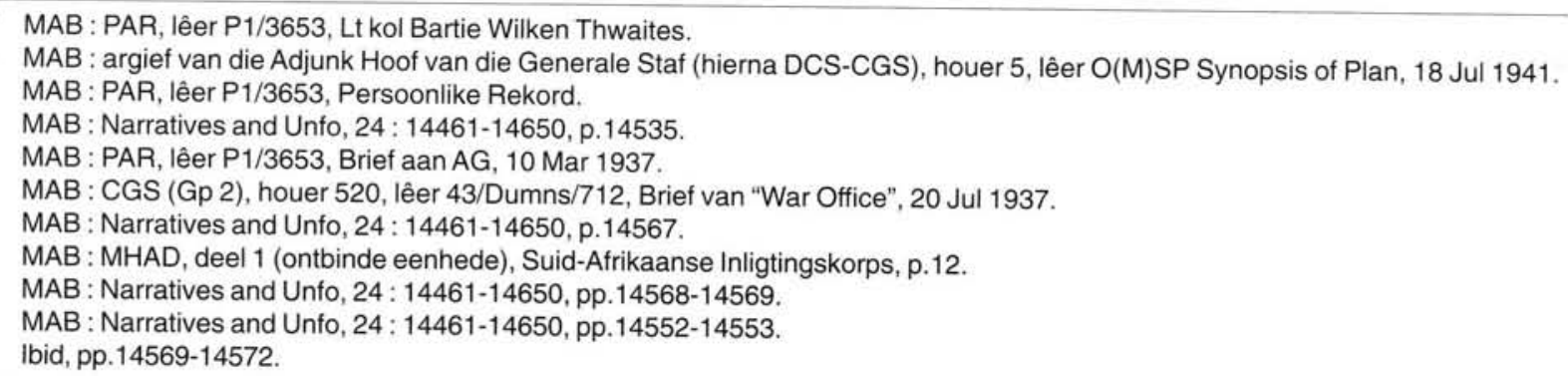


om betaalde agente te werf. ${ }^{38}$ Die volgende probleem was om die fondse deur die Parlement goedgekeur te kry, sonder om volledige rekenskap oor die aanwending daarvan te gee. Die probleem is opgelos deur ' $n$ Britse gebruik te aanvaar, waarvolgens ' $n$ sertifikaat ingevul moes word en daar dan verder op die integriteit van die inligtingsoffisier gesteun moes word. ${ }^{39}$ Onderskeid is gemaak tussen twee tipes agente: deeltydse agente het sewe sjielings en ses pennies ' $n$ dag gekry, terwyl permanente agente tot $£ 30$ ' $n$ maand kon ontvang. Dié salarisse was aangepas vir getroude mans en vir reisdoeleindes. ${ }^{40}$ ' $n$ Agent moes ' $n$ kwitansie uitskryf wat later gesertifiseer is deur die Sekretaris van Verdediging, die HGS en ADMI! Die ADMI het $£ 1250$ vir dié doeleindes in die periode tot 31 Maart 1940 ontvang. ${ }^{41}$ (Met ander woorde sowat tien permanente agente!) Gerigte agente is in die Unie en Portugees-Oos-Afrika aangewend om spesifiek inligtingsbehoeftes te bevredig. ${ }^{42}$

Hierdie insamelingsaktiwiteite het klaarblyklik alreeds voor die oorlog ' $n$ aanvang geneem. Harry Klein, ' $n$ joernalis, is byvoorbeeld gewerf om op die herdenking van die Groot Trek in 1938, te spioeneer. Insameling is oor Manie Maritz, die nasionalistiese leier, gedoen. Kommunikasie het geskied deur It kol Thwaites se kantoor by die Star, wat die aard van ' $n$ frontmaatskappy aangeneem het. ${ }^{43}$ Die tipe aktiwiteite is natuurlik nie altyd versoenbaar met ' $n$ Militêre Inligtingafdeling nie en hervorming sou nodig word.

Kolonel Thwaites (bevorder met sy aanstelling) is gevolglik op 25 September 1939 aangestel as Direkteur Inligting, met It kol E.J. McGarel Groves as sy adjunk. Omdat beide die persone hulle aandag bepaal het by "burgerveiligheid", moes voorsiening gemaak word vir ' $n$ suiwer Militêre Inligtingsfunksie en dié is dan ook verkry met die aanstelling van It kol H.T. Newman (Koninklike Mariniers) as ADMI onder kol Thwaites. ${ }^{44} \mathrm{Kol}$ Thwaites se belang in binnelandse veiligheid het gelei tot die aanstelling van "Bevelsinligtingsoffisiere" om informasie in die Unie in te samel. ${ }^{45}$

Die organisasie van militêre inligting was nou as volg: die Direkteur Inligting (kol B.W. Thwaites), ${ }^{46}$ met kapteins Meyer en Douglas, was vir "burgervei-

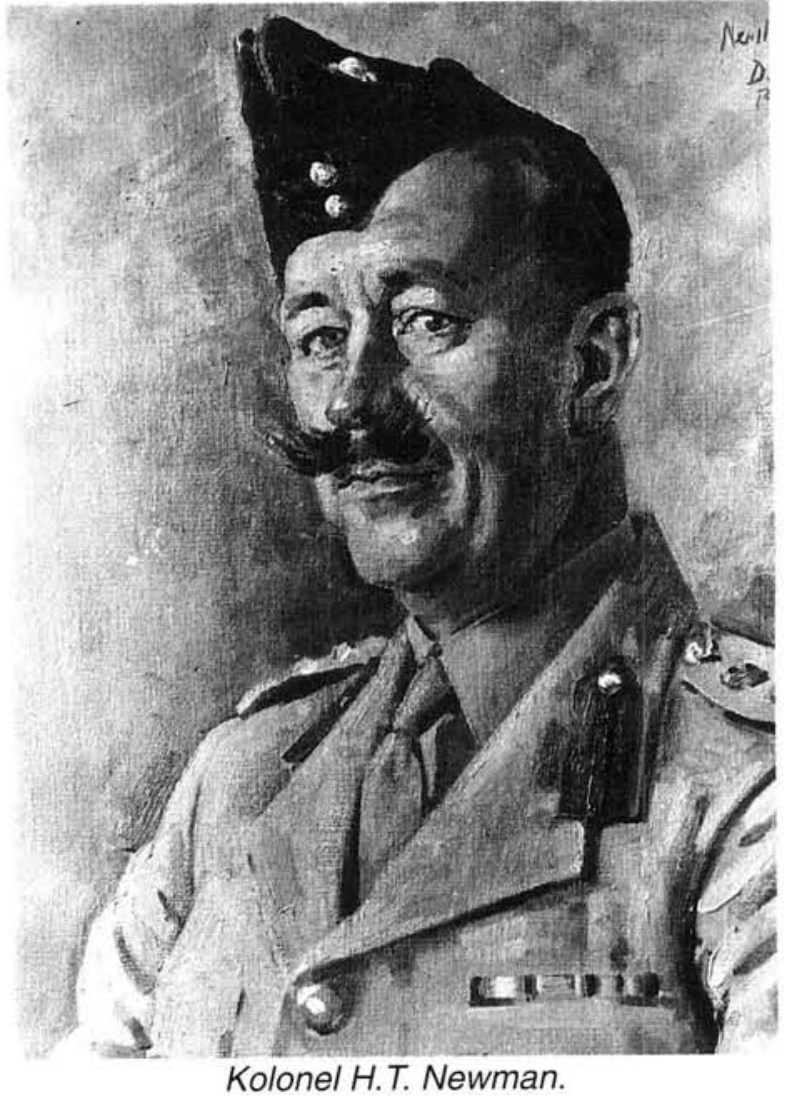

ligheid", plaaslike sensuur en propaganda verantwoordelik. ${ }^{47}$ Die ADMI (It kol H.T. Newman) met twee majore, ' $n$ kapt Bellwood en It Du Toit, ${ }^{48}$ was vir alle militêre inligting en sekerheid van die UVM verantwoordelik, tesame met pligte ten opsigte van die Mobiele Frontmag (MFF). ${ }^{49}$ Daar was dus nou twee aparte inligtingsafdelings by Verdedigingshoofkwartier.

\section{DIE HERORGANISASIE VAN INLIGTING IN SUID-AFRIKA}

Teen Mei 1940 was die stand van inligting onbevredigend. Daar was baie onduidelikheid, oorvleueling en oponthoud in die insameling en verspreiding van informasie. Inligting het uit verskillende bronne gekom, wat verskillende departemente in die Unie beïnvloed het. Geen riglyne vir verspreiding het bestaan nie, met die gevolg dat sensitiewe inligting doelloos gesirkuleer is sonder dat enige optrede

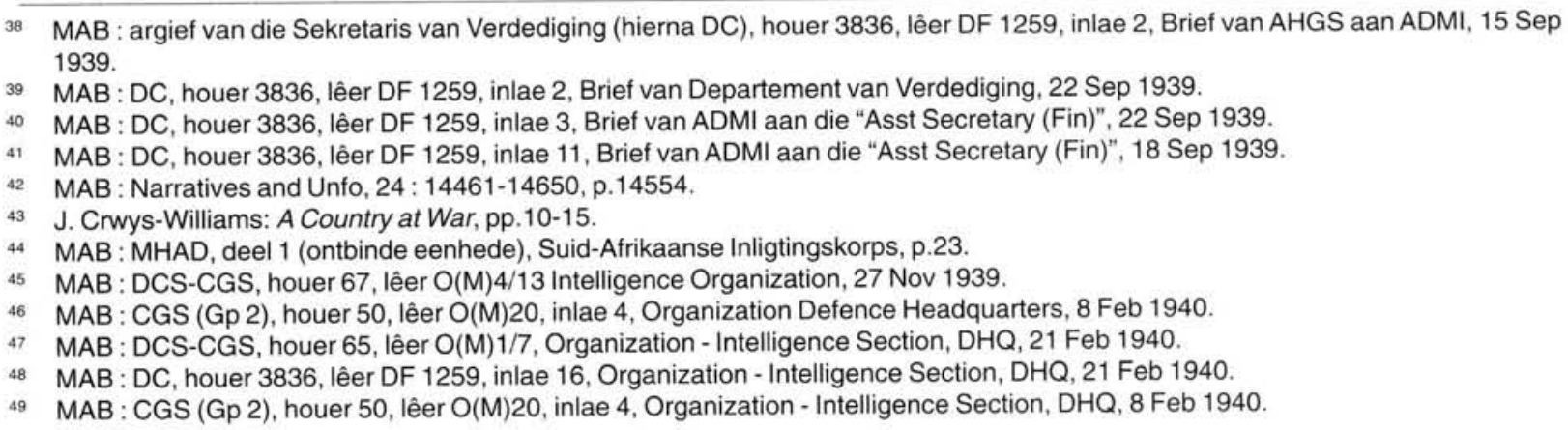


Hoof van die Generale Staf

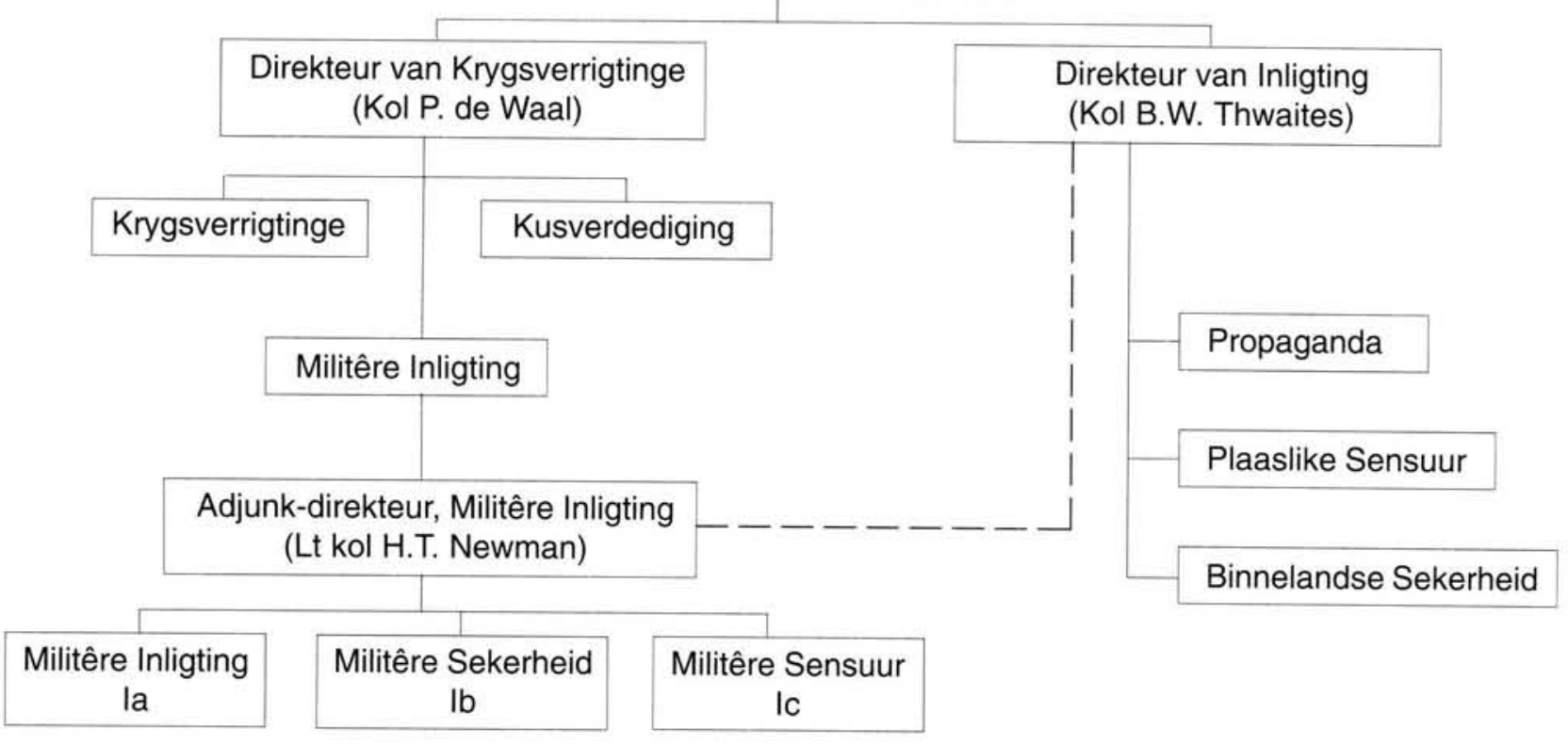

Figuur A : Die Organisasie van Militêre Inligting, Februarie 1940.

Bron: SANWA MHAD, deel 1 (Ontbinde eenhede), Suid-Afrikaanse Inligtingskorps, p.23.

geneem is..$^{50}$ Daar was minstens vier organisasies wat binnelands informasie ingesamel het. ' $n$ Lt kol Geotzche het byvoorbeeld sy eie struktuur ontwikkel. Die bevelsinligtingsoffisiere se werk het oorvleuel met dié van die Polisie. Hoewel daar erken is dat dit moeilik was om in die Unie onderskeid te tref tussen burgerlike en militêre inligting, moes verantwoordelikhede duideliker toegewys word. ${ }^{51}$

Om dié probleme op te los is ' $n$ Departementele Komitee oor Binnelandse Veiligheid aangestel. Dit het bestaan uit it kol Newman, kol Lendrum, kol Stanford en mnr Kincaid en het op 23 Mei 1940 vergader. ${ }^{52}$ ' $n$ Verdedigingsadvieskomitee onder Deneys Reitz en F. Claud Sturrock het uiteindelik op 27 September 1940 ' $n$ reeks aanbevelings aan die Minister van Verdediging voorgelê..$^{53}$ Dié aanbevelings sou tot die herstrukturering van die inligtingsgemeenskap lei.

' $n$ "Intelligence Clearance Bureau" onder kol H.J. Lenton, Kontroleur van Sensuur, is aangestel om die binnelandse veiligheidsaspek van inligting te hanteer. ${ }^{54}$ Die buro moes as sentrale punt vir die ontvangs, optekening en verspreiding van inligting dien. Alle informasie oor subversie, dislojaliteit en verdagte.persone moes aan die buro oorgedra word. Die buro het verteenwoordigers van Militêre
Inligting, Vlootinligting, Polisie, Binnelandse Sake en Sensuur ingesluit, wat op ' $n$ daaglikse basis in akkommodasie van die Posmeester-generaal vergader het. Voorsiening is vir ' $n$ klein ondersteuningstaf gemaak. ${ }^{55}$

Die "Intelligence Clearance Bureau" het in 1942 die "Intelligence Records Bureau" geword. Dit sou direk onder die Minister van Binnelandse Sake funksioneer, met brigadiers Lenton en Baston en kol sir Theo Truter in beheer. Dit het steeds al die ou funksies van die "Intelligence Clearance Bureau" gehad, maar dit het nou ' $n$ sentrale kantoor omvat wat uit verteenwoordigers van Sensuur, Polisie, Spoorwegpolisie, Militêre Inligting, Immigrasie, Doeane en Finansies bestaan het. Die buro is verbied om self ondersoeke of operasies te loods en moes primêr rekords byhou. ${ }^{56}$ Mnr Louis Esselen, Minister van Binnelandse Sake en ' $n$ vertroueling van generaal Smuts, is deur Amerikaanse waarnemers aan J. Edgar Hoover (FBI) gelyk gestel. Binnelandse veiligheid het uiteindelik sy verantwoordelikheid geword. ${ }^{57}$

Kol Thwaites se pos is in Oktober 1940 afgeskaf en hy moes sy kontant en rekords aan kol Lenton oorhandig. ${ }^{58} \mathrm{Kol}$ Thwaites is verplaas as Bevelvoerder Kommandement Witwatersrand en al die funk-

\footnotetext{
MAB : CGS WAR, bondel 49/15, vol 1, inlae 23, Brief van HGS aan AG, 25 Okt 1940.

MAB : DC, houer 3512, lêer 17926/29, Departmental Committee on Internal Security, 22 Mei 1940.

MAB : CGS WAR, bondel 49/15, vol 1, inlae 23, Brief van HGS aan AG, 25 Okt 1940.

MAB : DC, houer 3512, lêer 17926/29/3, Brief van Binnelandse Sake aan Sekretaris van Verdediging, 30 Okt 1940.

MAB : CGS WAR, bondel 49/15, vol 1, inlae 23, Brief van HGS aan AG, 25 Okt 1940.

MAB : CGS WAR, bondel 49/15, vol 1, inlae 23, Brief van Verdedigingsadvieskomitee aan Minister van Verdediging, 27 Sep 1940.

F.D. Tothill : The 1943 General Election (ongepub MA tesis, UNISA Nov 1987), pp.12-25. MAB : DC, houer 3512, lêer 17926/29/3, Brief van Minister van Binnelandse Sake aan die Sekretaris van Verdediging, 28 Okt
1940.

MAB : MHAD, deel 1 (ontbinde eenhede), Suid-Afrikaanse Inligtingskorps, pp.23-25.
} 


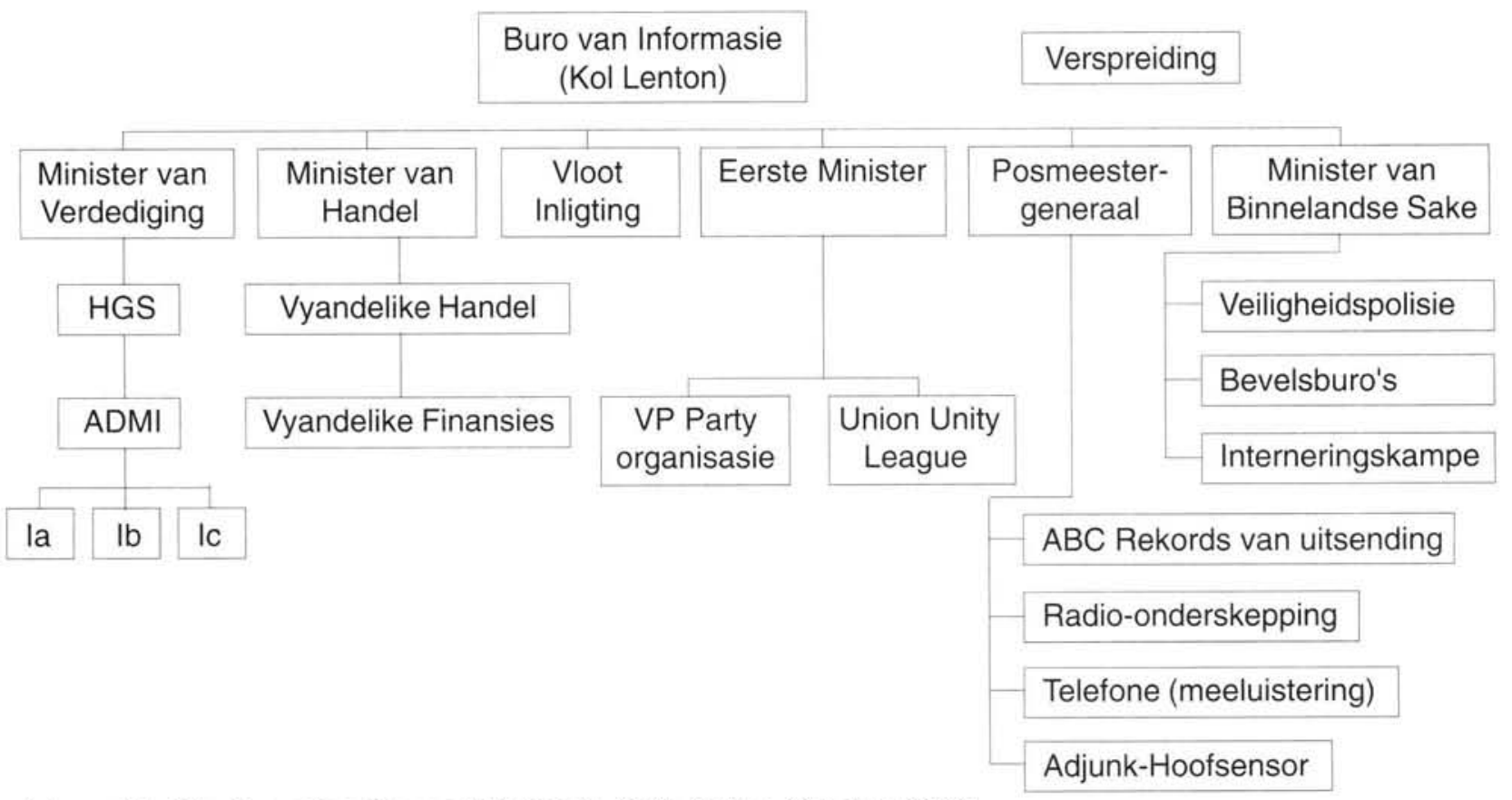

Figuur B : Die Organisasie van Inligting in Suid-Afrika, Oktober 1940.

Bron: SANWA ARMY (Gp 1) 55, lêer PR 1/7, Diagram, ongedateerd (na Oktober 1940).

sies en personeel wat nie na die "Intelligence Records Bureau" oorverplaas is nie, het deel van die nuwe stafafdeling, Direkteur Militêre Krygsverrigtinge en Inligting, geword. Kol Newman het dié pos hanteer saam met sy amp as ADMI. ${ }^{59}$ Kol Newman is teen Maart 1942 terugverplaas na Londen en vervang deur kol R. Campbell Ross, met It kol Kreft as ADMI.$^{60}$ Die Militêre Inligtingafdeling was natuurlik nie net belas met burokratiese herorganisasie nie, maar moes ook in 1940 vir ' $n$ inligtingstruktuur te velde voorsiening maak.

\section{DIE INLIGTINGSORGANISASIE TE VELDE (MFF)}

Lt kol Newman het reeds in Maart 1940 sy kommer uitgespreek oor die swak stand van gereedheid van sy afdeling om te velde te funksioneer. ${ }^{61}$ Die inligtingsaanduidings het ' $n$ mobiele oorlog in die somer van 1940 voorspel en daar is vir die veiligheid van Kenia gevrees..$^{62}$ Lt kol Newman is verantwoordelik gemaak vir die daarstel van ' $n$ inligtingskorps vir die Mobiele Veldmag (MFF) wat in Oos-Afrika ontplooi sou word. ${ }^{63}$ Daar is egter alreeds in November 1939 begin werk aan die sogenaamde Ixorganisasie. $^{64}$

Die Ix-organisasie sou, met enkele modifikasies, volgens die Britse model georganiseer word. Dit sou as ' $n$ skadustruktuur binne die ADMI se staf funksioneer totdat dit gemobiliseer word. Die Ix-

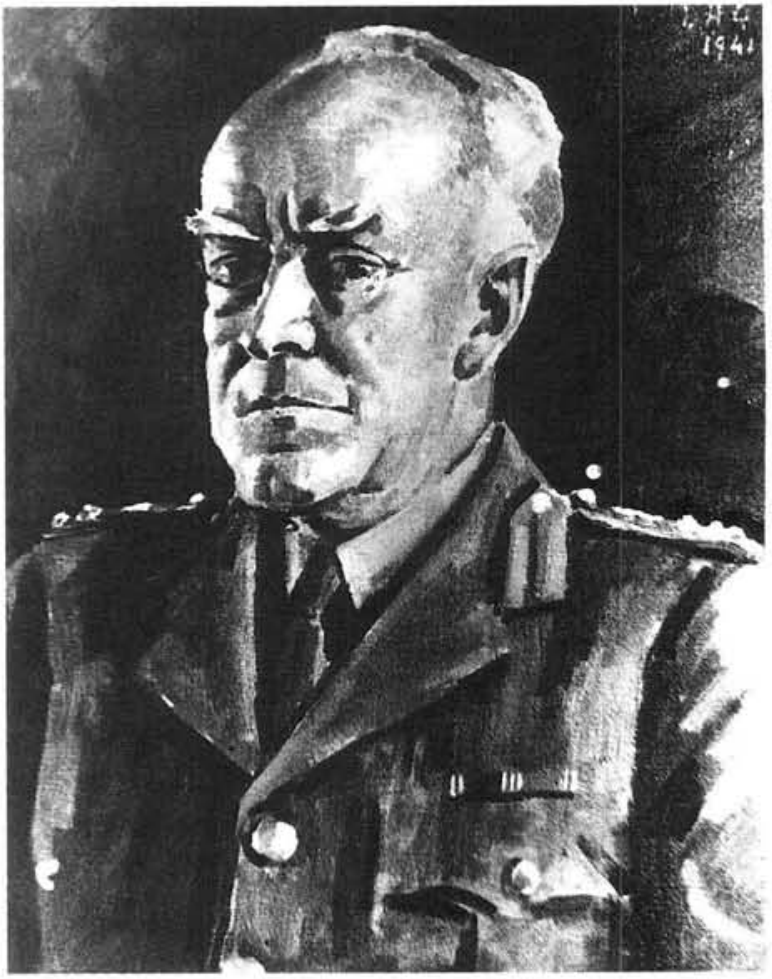

Brigadier H.J. Lenton.

staf was vir die organisering, koördinering en administrasie van militêre inligting te velde verantwoordelik. Inligtingsprodukte en 'n oorlogsdagboek moes geproduseer word en skakeling moes met die Kommandant, Inligtingskorps plaasvind. Die Ix-staf is

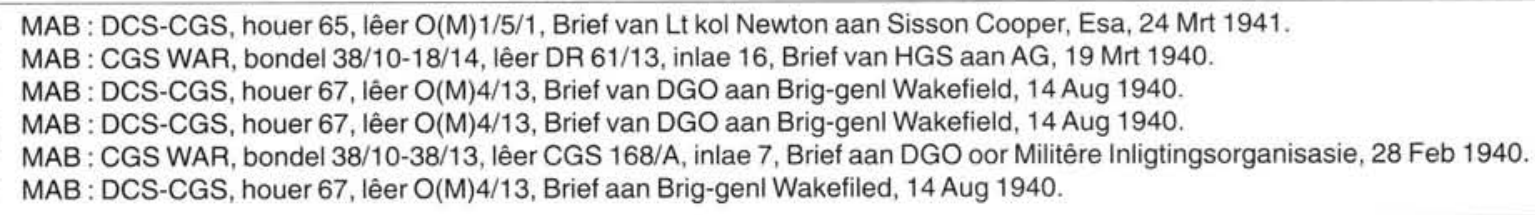


in drie seksies verdeel. Seksie la (Informasie) was vir die verwerking en verspreiding van inligting verantwoordelik. Seksie lb (Veiligheid) was vir insameling en sekerheid te velde verantwoordelik. Seksie Ic (Sensuur, publisiteit en propaganda) was weer vir sensuur, skakeling, mediaskakeling, propaganda en rekords verantwoordelik. ${ }^{65}$ Twee stelle pligstate is saamgestel, een vir die Militêre Inligtingafdeling en die ander vir wanneer die offisier saam met die MFF sou ontplooi. ${ }^{66}$

Personeel was ' $n$ groot probleem vir die mag. Die Militêre Inligtingafdeling het op 27 November 1939 uit 31 offisiere en 42 onderoffisiere (insluitende veldsekerheidspolisie) bestaan. Daar is op offisiere met vorige ondervinding in Generale Staf Inligtingswerk (' $\mathrm{n}$ ietwat skaars kommoditeit) gekonsentreer. Die meeste inligtingsoffisiere het slegs ondervinding van binnelandse veiligheid gehad en het nie kennis gedra van formasies en eenhede te velde nie. Slegs kol Thwaites en kapteins Lavin en Chapman het voorheen formasie-oefeninge bygewoon. 67 ' $n$ Inligtingskorps is uiteindelik op 1 Februarie 1940 gestig (SA Inligtingsdiens). ${ }^{68}$ Teen Januarie 1941 was die mag 32 offisiere en 68 onderoffisiere sterk. ${ }^{69}$ Die "korps" was egter nie op die stadium ' $n$ inligtingskorps soos wat die term vandag verstaan word nie. Dit moet eerder vergelyk word met ' $n$ eenheid wat gestig is vir ' $n$ spesifieke doel.
Die korps het baie goeie werk verrig en het die enigste veldsekerheidspolisie, radio-onderskepping en publisiteitsvermoë in Kenia verskaf. Die MFF-inligtingstaf het primêr, dog nie uitsluitlik nie, uit UVMpersoneel bestaan. Dit het ' $n$ probleem geword toe 'n Oos-Afrika-inligtingskorps in Januarie 1941 gestig is. ' $n$ Groot stryd tussen die UVM en die Britse magte het oor die bevel van dié korps ontstaan. ${ }^{70}$ Die probleem is opgelos deur die hoof van Ix die bevelvoerder van die korps te maak, terwyl die SuidAfrikaanse Inligtingskorps steeds die personeelaangeleenthede van UVM-personeel behartig het. ${ }^{71}$ Die Suid-Afrikaanse Inligtingskorps, onder maj Hallier, het parallel met die Oos-Afrika-inligtingskorps gefunksioneer, hoewel hulle een eenheid gevorm het. $^{72}$

\section{DIE WERKING VAN MILITÊRE INLIGTING}

Teen Augustus 1943 het die Militêre Inligtingafdeling van die UVM sy finale vorm bereik. Dit was nou ' $n$ direktoraat gelykstaande aan die Direktoraat van Militêre Operasies. Die Direkteur Militêre Inligting (DMI), It kol E.G. Malherbe, ${ }^{73}$ was verantwoordelik vir die organisering van Militêre Inligting, die insameling en verspreiding van inligting, skakeling met Ge-

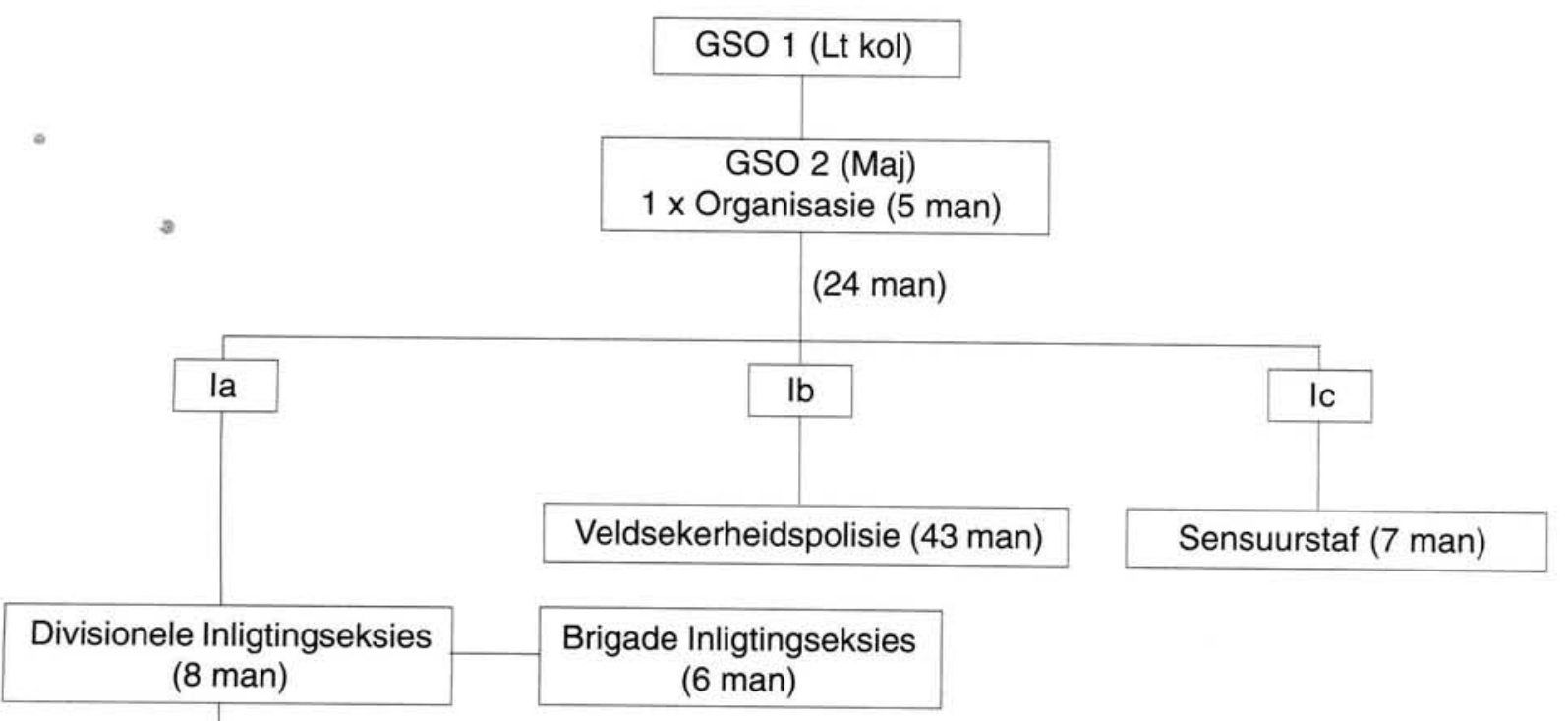

Luginligtingseksies

(7 man)

Figuur C : Die Organisasie van die SA Inligtingskorps (MFF), Januarie 1941.

Bron: SANWA DCS CGS 65, Lêer O(m) 1/7, DMO en I, 11 Januarie 1941.

MAB : DCS-CGS, houer 67, lêer O(M)4/13, inlae 1, Inligtingsorganisasiekonsep, Aanhangsel, 27 Nov 1939.

MAB : argief van die Hoof van die Lëer (hierna ARMY) Gp 1, houer 55, lêer PR 1/2/2, Organisasie-uitleg (GHQ), 4 Mrt 1940,

MAB : DCS-CGS, houer 67, lêer O(M) 4/13, inlae 1, Inligtingsorganisasiekonsep, 27 Nov 1939.

MAB : Eenheidsgeskiedenis lêer, vol 1, SA Inligtingskorps.

MAB : DCS-CGS, houer 65, lêer O(M) 1/7, Brief van It kol H.T.Newman aan HGS, 4 Jan 1941.

MAB : DCS-CGS, houer 65, lêer O(M) 1/7, Seinberig van DECHIEF aan FORCE Nairobi, ongedateerd.

MAB : DCS-CGS, houer 65, lêer O(M) 1/7, Seinberig van FORCE aan DECHIEF, 10 Feb 1941.

MAB : DCS-CGS, houer 65, lêer O(M) 1/7, Brief aan lt kol R.A. Hutton, 5 Feb 1941.

MAB : PAR, lêer P 1/18223 Lt kol E.G.Malherbe. 
allieerde inligtingsdienste, beheer oor die UVM-filmeenheid, Oorlogsmuseum en Historiese Rekordtak, en die uitvoering van die UVM se beleid oor leëropvoeding. ${ }^{74}$ (Kyk Aanhangsel E.) Ten einde sy taak te verrig, is Militêre Inligting in drie seksies verdeel: Seksie la (Informasie), Seksie lb (Sekerheid) en Seksie Ic (Sensuur).

\section{DIE ROL EN FUNKSIES VAN SEKSIE Ia (INFORMASIE)}

Seksie la (Informasie) was primêr vir die verwerking en verspreiding van inligting verantwoordelik. Die breë organisasie van die seksie, met vyf onderafdelings onder bevel van ' $n$ majoor, het reeds in November 1940 sy beslag gekry. ${ }^{75}$

Subseksie la(i) was vir vyandelike oogmerke en operasies verantwoordelik. ' $n$ Kaartindeks van vyandelike organisering, samestelling en groeperings moes saamgestel word. Daar moes ook op hoogte van geallieerde politieke en militêre verwikkelinge gebly word. Maatreëls moes getref word vir die uitbuiting van bronne en skakeling met Geallieerdes moes bewerkstellig word. ${ }^{76} \mathrm{Kol}$ Thwaites het met genl Wavell (bevelvoerder van die Agste Leër in Noord-Afrika) geskakel om inligtingsamewerking te verkry. ${ }^{77}$ ' $n$ Inligtingsdagboek moes ook bygehou word. Die hoofproduk van die subseksie (in samewerking met ander subseksies) was die weeklikse inligtingsopsommings ${ }^{78}$

Subseksie la(ii) was vir die daarstel van ' $n$ slagorde verantwoordelik. ' $n$ Kaartindeks van vyandelike bevelvoerders, formasies en eenhede moes saamgestel word. Aandag moes ook aan vyandelike werwing en opleiding, sowel as reserwes en verliese geskenk word. Dieselfde moes gedoen word met eie en geallieerde magte (in teenstelling met moderne inligtingspraktyk). Hierdie informasie moes in ' $n$ dagboek bygehou word, terwyl bydraes vir die weeklikse inligtingsopsomming gelewer is. ${ }^{79}$

Subseksie la(iii) was vir vyandelike verdedigingswerke, hulpbronne en logistieke lyne verantwoordelik. Dié subseksie was voorts met tegniese data en statistiek van vyandelike wapentuig en uitrusting belas. Rekord moes gehou word van vyandelike opslagplekke, terwyl topografiese inligting ingesamel is en kaarte en demografiese inligting ook bygehou is. ${ }^{80}$

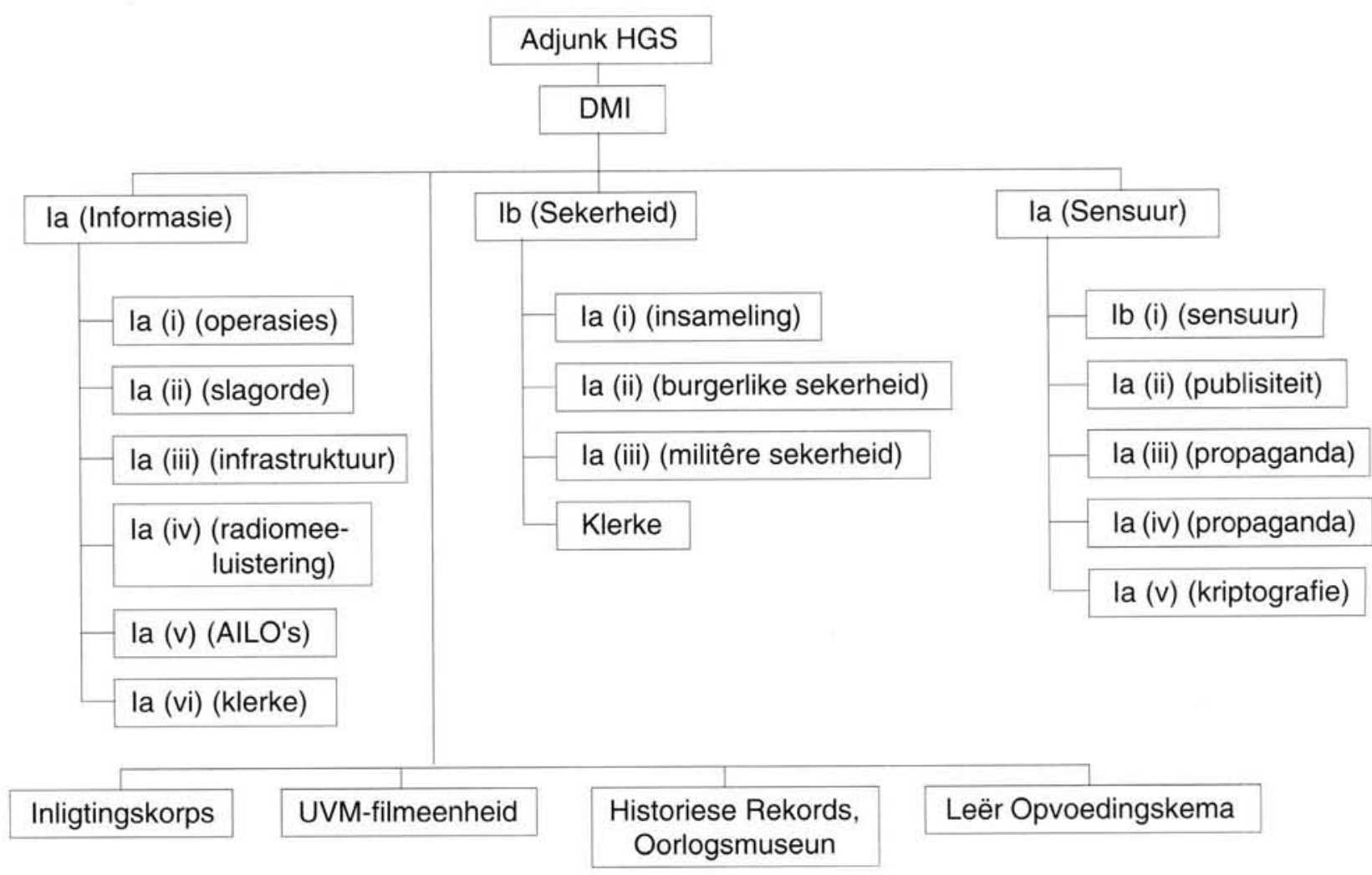

Figuur D : Die organisasie van Militêre Inligting teen 1943.

Bron: SANWA CGS WAR 38/1 - 38/10, Organisasietabel, ongedateerd na 1942).

74 MAB : CGS WAR, bondel 38/6, AG(W)168/2/2/2, inlae 6, Brief van AG aan HGS, 13 Jul 1943.

75 MAB : ARMY (Gp 1), houer 55, lêer PR 1/2, Organisasietabel MI, 22 Nov 1940.

76 MAB : ARMY (Gp 1), houer 55, lêer PR 1/2/2, ADMI se uiteensetting van pligte, 4 Mrt 1940.

7 MAB : CGS WAR, bondel 38/10-38/13, lêer 168/17/A, inlae 7, Seinberig van HGS aan AHGS, 18 Mrt 1940.

7. MAB : ARMY (Gp 1), houer 55, lêer PR 1/2/2, ADMI se uiteensetting van pligte, 4 Mrt 1940.

Ibid.

so MAB : ARMY (Gp 1), houer 55, lêer PR 1/2/2, ADMI se uiteensetting van pligte, 4 Mrt 1940. 
Subseksie la(iv) was vir die moniter van vyandelike radioberigte verantwoordelik. Die werk het uit kriptografie, radio-onderskepping en telefoon- en telegrammeeluistering bestaan. Samewerking is met die seinkorps verkry (kyk bespreking van radiomeeluistering). 'n Dagboek moes ook bygehou word, tesame met weeklikse bydraes vir die inligtingsopsomming. ${ }^{81}$

Subseksie la(v) was by lugmagsamewerking betrokke. Fotoverkenning en ander vorms van luginsameling moes in samewerking met die luginligtingskakeloffisiere ('Air Intelligence Liaison Officer' of AILO) gereël word. ${ }^{82}$

Al vyf die subseksies het uit twee tot drie offisiere met ' $n$ klein staf bestaan. Die klerklike personeel was georganiseer as subseksie la(vi). ${ }^{83}$ Daar moet op gelet word dat Seksie la nie self insameling gedoen het nie, dit was die verantwoordelikheid van Seksie lb.

\section{DIE ROL EN FUNKSIES VAN SEKSIE Ib (SEKERHEID)}

Die Seksie lb was vir die insameling van informasie deur spesiale metodes en vir militêre veiligheidsinligting verantwoordelik. Die bevelsinligtingsoffisiere, voorlopers van die veldsekerheidsoffisiere, was onder die bevel van dié seksie. Seksie lb was onder bevel van ' $n$ oud-polisiemajoor. ${ }^{84}$ Die hoof van die seksie was aanvanklik kapt J.A. Reay (tot Desember 1940), waarna maj E.A. Gibbs bevel oorgeneem het. ${ }^{85}$ Die meeste van die staflede van Seksie lb was ook oud-polisiemanne of lede van die Speurtak (CID) omdat hulle die beste agtergrond vir die taak gehad het. Kol Thwaites se fokus op sekerheid het van Seksie lb 'n belangrike seksie gemaak. ${ }^{86}$ Die Seksie lb-staf was ook vir die administrasie van hawesekerheidsoffisiere verantwoordelik. Met dié doel voor oë is 'n streekskantoor in Kaapstad gestig wat weer vir roetine-aangeleenthede onder die bevel van die Kusgebiedhoofkwartier gefunksioneer het. ${ }^{87}$

Daar bestaan onduidelikheid oor die organisering van Seksie lb. Dit wil voorkom asof die insame- lingstaak onder subseksie $\mathrm{lb}(\mathrm{i})$ geresorteer het. Daar moes klaarblyklik gekonsentreer word op suiwer militêre aspekte, hoewel orkeste en klubs in Suidwes-Afrika ook teikens vir insameling was. In dié opsig moes daar samewerking met die SuidAfrikaanse Polisie plaasvind ${ }^{88}$ Informasie oor subseksie lb(i) is moeilik bekombaar en dit wil voorkom asof dié subseksie se rekords vernietig is.

Die subseksie lb(ii), onder die bevel van ' $n$ kaptein, was vir burgerlike inligting verantwoordelik. ${ }^{89}$ Hierdie afdeling sou klaarblyklik konsentreer op die invloed van burgerlikes op militêre sekerheid en sou dus nie met kol Thwaites en later kol Lenton se werk oorvleuel nie. Subseksie lb(iii), onder bevel van 'n luitenant, was weer vir militêre sekerheid verantwoordelik. Hier het die aandag op die beskerming van militêre personeel, uitrusting, basisse en operasies teen spioenasie en sabotasie geval. Dié subseksie was dus belas met teeninligting en die ondersoek van verdagtes. ${ }^{90}$

Seksie lb het ook twee klerke en ' $n$ tikster op sterkte gehad. ${ }^{91}$ Die Seksie Ib-staf het sekerheidsvoorligtings ${ }^{92}$ aangebied en sekerheidsvraelyste is aan bevelvoerders gesirkuleer. ${ }^{93}$ ' $n$ Nuwe klassifikasiestelsel vir dokumentasie is ook ontwikkel met die volgende kategorieë: uiters geheim, geheim, sekuriteit, vertroulik en nie vir publikasie. ${ }^{94}$ Die Seksie Ib-staf het dus ' $n$ belangrike, dog moeilike omskryfbare, taak verrig. (Kyk bespreking van veldsekerheidspolisie.)

\section{DIE ROL EN FUNKSIES VAN SEKSIE IC (SENSUUR)}

Die Ic-seksie, onder die bevel van 'n majoor, was primêr vir sensuur in die UVM verantwoordelik. Teen Maart 1939 was voorbereidings vir die instel van sensuur in die Unie, byna voltooi. Memorandums en proformas is vir staatsdepartemente voorberei om die instel van sensuur te vergemaklik. ${ }^{95}$ Die doel van sensuur was tweeledig. Eerstens moes verhoed word dat die vyand bruikbare informasie $\mathrm{kry}$, of dat informasie wat nadelig was vir moraal, versprei word. Tweedens moes informasie oor die vyand en oor die moraal en lojaliteit van eie magte 
ingesamel word. Die verantwoordelikheid vir sensuur is verdeel tussen die UVM en burgerlike instansies. ${ }^{96}$ Die Ic-seksie het op die sensuur van eie magte in die Unie en te velde gekonsentreer en was in vyf subseksies georganiseer.

Subseksie Ic(i), bestaande uit 'n kaptein en luitenant, was in beheer van die eintlike sensuurfunksie. ${ }^{97}$ In die Unie was veldsensuurseksies in Pretoria, Kaapstad, Durban en Bloemfontein (18 offisiere en 38 ander range) gesetel. ${ }^{98}$ Veldsensuurafdelings is saam met die magte te velde ontplooi en omvattende rapporte is oor die stand van moraal en houdings teenoor spesifieke onderwerpe saamgestel. Daar was ongelukkig pogings om dié hulpmiddel vir politieke gewin uit te buit, veral vir die doeleindes van die verkiesing in die Unie. ${ }^{99}$ Plaaslike bevelvoerders het dit egter afgekeur. ${ }^{100}$ Sensuur het uit eenheidsensuur en basissensuur bestaan, waar korrespondensie op ' $n$ steekproefbasis oopgemaak is. ${ }^{101}$ Troepe is met velddiensposkaarte (slegs adresse) en groen koeverte vir persoonlike items uitgereik om die sensor se taak te vergemaklik. ${ }^{102}$ In gevalle waar sensuurreëls oortree is, is eenheidsbevelvoerders, Seksie lb en ander instansies in kennis gestel om die nodige tugstappe te doen. ${ }^{103}$

Subseksie Ic(ii) was vir publisiteit verantwoordelik en het aanvanklik uit een luitenant bestaan. Dié werk was nou verwant aan dié van subseksies lc(iii) en Ic(iv), wat vir propaganda verantwoordelik was. ${ }^{104}$ Die subseksie Ic(iii) het produkte "vervaardig" terwyl subseksie Ic(ii) dit "bemark" het. ${ }^{105}$ Eenheidsinligtingsoffisiere is gevra om weekliks propaganda-opsommings na Seksie Ic te versend, sodat temas daaruit ontwikkel kon word. Aandag is gegee aan vyandelike propaganda, sodat teenpropaganda ontwikkel kon word. ${ }^{106}$ Die teikens van propaganda was verdeel in eie magte, vyand en neutrales. Daar is besef dat die vyand ' $n$ voorsprong in propaganda gehad het, maar dit was 'n faset van oorlog waar ' $n$ totale poging ingesit moes word om ' $n$ oorwinning te bewerkstellig. So moes anti- oorlog-media gediskrediteer word en onbewuste elemente moes as kanale vir propaganda aangewend word. ${ }^{107}$ Die propagandastaf het van alle media gebruik gemaak, maar die radio is as besonder belangrik beskou, omdat die UVM goeie toegang daartoe gehad het (die SAUK het 'n monopolie uitgeoefen). Pogings is aangewend om gevorderde radio-opnametoestelle uit die VSA vir die ses opname-eenhede te velde te koop. In September 1944 , het dit hoë prioriteit geniet omdat die tuisfront "wankelrig" voorgekom het. ${ }^{108}$

'n Spesiale kriptografiese element (subseksie lc(v)) bestaande uit drie offisiere en vyf ander range, het deel van Seksie Ic uitgemaak. Hulle spesifieke funksie was onduidelik. Die Seksie Ic is deur ' $n$ kantoorstaf van onderoffisiere ondersteun wat vir die tiken sekretariële dienste verantwoordelik was. ${ }^{109}$ Hoewel sensuur en propaganda nie normaalweg die taak van 'n Militêre Inligtingsafdeling is nie, het die Unie se besonderse omstandighede sulke maatreëls genoodsaak. ${ }^{110}$

\section{KOMPONENTE VAN DIE MILITÊRE INLIGTINGSVERMOË 1940-1943}

\section{DIE INLIGTINGSKORPS}

Die Inligtingskorps was die belangrikste komponent van die militêre inligtingsvermoë. Dit het die "senuwees" van die UVM se inligtingstruktuur gevorm. Die Inligtingskorps sou groei uit die MFF se inligtingskorps wat in Februarie 1940 gestig is. ${ }^{111}$ Dit wil voorkom asof alle inligtingpersoneel teen Oktober 1943 lid van die inligtingskorps was - met ander woorde ook die lede van die Militêre Inligtingafdeling. ${ }^{112}$ Lt kol E.G. Malherbe is ook op 24 Augustus 1943 oorgeplaas na die inligtingskorps, toe hy Direkteur van Militêre Inligting (DMI) geword het. ${ }^{113}$

'n Uiteensetting van die Inligtingskorps se oorlogstabel op 9 Maart 1940 gee ' $n$ blik op die stand van

\footnotetext{
MAB : ARMY (Gp 1), houer 69, lêer PR 14/2/k, Precis van sensuurvoorligting, ongedateerd.

MAB : ARMY (Gp 1), houer 55, lêer PR 1/2, Organisasietabel MI, 22 Nov 1940.

MAB : AG (Gp 1), houer 194, lêer AG736/115/1, inlae 50, Brief van kol J.Davies aan DMI, 10 Mar 1943.

F.D. Tothill : The 1943 General Election.

100 MAB : CGS WAR, bondel 49/17, lêer UDF/321/11(A) Field Censorship, Brief aan kol R.Campbell-Ross oor veldsensuur, 24 Aug 1944.

101 MAB : ARMY (Gp 1), houer 69, lêer PR 14/2/K, Precis van sensuurvoorligting, ongedateerd.

102 MAB : ARMY (Gp 1), houer 54, Precis van voorligting, veiligheid en sensuur, 23 Jan 1940.

103 MAB : ARMY (Gp 1), houer 69, lêer PR 14/2/K, Uitleg van prosedure vir die opvolg van sensuurverslae, ongedateerd.

104 MAB : ARMY (Gp 1), houer 55, lêer PR 1/2, Organisasietabel Militêre Inligting, 22 Nov 1940.

105 MAB : ARMY (Gp 1), houer 55, lêer PR 1/2/2, Uiteensetting van die herorganisasie van lc-staf (MFF), ongedateerd.

106 MAB : ARMY (Gp 1), houer 55, lêer PR 1/2/2, Memorandum van Lt J.E.Sacks (Ic(iii)), 21 Aug 1940.

107 MAB : ARMY (Gp 1), houer 55, lêer PR 1/2/1, Memorandum van Lt J.E.Sacks (Ic(iii)), 8 Aug 1940.

108 MAB : argief van die Militêre Attaché, London (hierna Mil Ad), houer 265, Diverse Lêer, Brief van D.Beadon oor opnametoestelle, 6 Sep 1944.

109 MAB : ARMY (Gp 1), houer 55, lêer PR 1/2, Organisasietabel MI, 22 Nov 1940.

110 MAB : Mil Ad, houer 265, Diverse Lêer, Brief van D.Beadon oor opnametoestelle, 6 Sep 1944.

111 MAB : Eenheidsgeskiedenislêer, vol 1, SA Inligtingskorps.

112 MAB: AG (Gp 1), houer 194, lêer AG 736/115/1, inlae 64, Brief van AG aan DMI, 11 Okt 1943.

113 MAB : PAR, lêer P 1/18223, Rekord van Lt kol E.G. Malherbe.
} 
die korps. Die korps het bestaan uit 'n hoofkwartier, 'n afdeling Groothoofkwartier, tien brigade-afdelings en verbindingslynafdelings by elke hawe. ${ }^{114} \mathrm{Die}$ hoofkwartier het uit die hoof of korpsdirekteur, die kommandant genoem, maj F.C. Hallier en die adjudant It L.F. Dawson, bestaan. ${ }^{115}$ Die totale sterkte van die korps was 233 manne waarvan 50 nie-blankes. Die totale offisiersterkte was 49 man. Daar was geen offisiere op brigadevlak nie. Die korps het oor agt fietse, 40 motorfietse, 13 motors, een vragmotor en 12 pistole beskik. Die meeste mannekrag (69) was in die MFF gekonsentreer. ${ }^{116}$ Teen Desember het die korps tot 178 man en 90 offisiere gegroei. ${ }^{117}$

Die korps het teen 1941 verskeie spesialisvakrigtings ontwikkel. Die belangrikste was die inligtingsoffisiere wat die inligtingseksies beman het. Verder was daar veldinligtingsoffisiere wat klaarblyklik onafhanklik gewerk het (moontlik insamelaars). Kodeskrifspesialiste is ook by hoofkwartiere en divisies afgedeel. Die veldsekerheidspolisie het heeltemal onafhanklik gewerk. Veldsensoroffisiere en lede van die spesialissensuurseksies het ' $n$ groot deel van die korps se ledetal uitgemaak. Nog ' $n$ spesialisrigting was die luginligtingskakeloffisiere, waarvoor daar teen 194116 poste was. ${ }^{118}$ Brigade- en verbindingslynafdelings is ook georganiseer en verskeie offisiere is aan imperiale eenhede toegewys. ${ }^{119} \mathrm{Hier}$ die spesialisasie het beteken dat bevordering te velde nie kon plaasvind nie en die kommandant moes senioroteitslyste streng byhou. ${ }^{120}$

Die kommandant het klaarblyklik gesukkel om opgeleide inligtingsoffisiere aan die eenhede te verskaf. Daar moes ook ' $n$ balans tussen die bevordering van personeel in die Unie en dié in operasionele gebiede gehandhaaf word. ${ }^{121}$ Bevordering is verder bemoeilik deur politieke aanstellings wat die Eerste Minister in die korps gedoen het. ${ }^{122}$

\section{DIE VELDSEKERHEIDSPOLISIE}

Die Veldsekerheidspolisie (VSP) was die uitvoerende been van Seksie lb. Die aktiwiteite van die VSP was onder bevel van die hoof van Seksie lb, hoewel hulle administratief onder die bevel van die onderskeie kommandemente en vestings was. Die doel van die VSP was om vyandelike spioenasie, propaganda en sabotasie te verhoed. Sekerheidsbreuke of die verontagsaming van sekerheidsregulasies moes ook opgespoor word. Misdade en dissiplinêre oortredings is nie ondersoek nie, tensy dit sekerheid beïnvloed het. Dissiplinêre optrede was die laaste uitweg wanneer ander middele gefaal het. ${ }^{123}$ Die VSP het arresbevoegdheid gehad, hoewel soveel as moontlik van dié werk aan die militêre of burgerlike polisie oorgedra moes word. ${ }^{124}$ Die VSP kan dus vergelyk word met die moderne teeninligtingsfunksie.

Die VSP was deel van die inligtingskorps wat spesifiek voorsiening vir seksies by hoofkwartiere en verbindingslyne gemaak het. ${ }^{125} \mathrm{VSP}$ is ook by kommandemente en opleidingsentra ontplooi. Konflik oor status het tussen die VSP en die Militêre Polisie ontstaan. Dit is opgelos deur die VSP-lede by die Militêre Polisie te attesteer, terwyl Militêre Inligting hulle aanwending beheer het. Bevel oor die VSP is gedesentraliseer deur hulle aan hulle eie bevelvoerders te laat rapporteer en deur die VSP-afdeling self beheer oor alle sekerheidsaangeleenthede binne hulle onderskeie verantwoordelikheidsgebiede te gee. ${ }^{126}$ Die VSP sou noodwendig moes skakel met die Stafinspekteur, Verdedigingsveiligheidmaatreëls (kol N.M.H. Bourne). ${ }^{127}$ Die aanstelling en toewysing van VSP-offisiere het egter by Militêre Inligting plaasgevind. ${ }^{128}$

Die VSP te velde was, bo en behalwe hulle normale take, ook vir die volgende verantwoordelik: alle kommunikasie tussen verowerde en vyandelike gebiede moes verhoed word; die VSP-offisier moes as hoofskakel tussen eie magte en die verowerde gebied se owerhede dien; vyandelike burgerlikes moes geklassifiseer word en hulle bewegings ingeperk word; en alle vyandelike uitrusting en hulpbronne moes deur die VSP beheer word. Die VSP was daarby klaarblyklik ook die hoofakteur in enige moontlike anti-partisaanaksies. ${ }^{129}$

VSP-onderafdelings in die Unie was by Pieterma-

\footnotetext{
4 MAB : CGS (Gp 2), houer 214, lêer 367/13/10, Oorlogstabel van SA Inligtingskorps, 9 Mar 1940.

MAB : AG (Gp 1), houer 194, lêer AG 736/115/2, Tabel van Inligtingskorpssterkte, 15 Apr 1941.

MAB : CGS (Gp 2), houer 214, lêer 367/13/10, Oorlogstabel van SA Inligtingskorps, 9 Mar 1940.

MAB : CGS (Gp 2), houer 214, lêer 367/13/10, Sterktetabel, ongedateerd.

MAB : AG (Gp 1), houer 194, lêer AG 736/115/2, Tabel van Inligtingskorpssterkte, 15 Apr 1941.

MAB : CGS (Gp 2), houer 214, lêer 367/13/10, Sterktetabel, ongedateerd.

120 MAB : argief van die Bevelvoerende-generaal, Unieverdedigingsmag (hierna UDF), houer 81, lêer UDF 816/5(A), Brief van Lt kol Kreft aan AG, 4 Feb 1942

121 MAB : UDF, houer 81, lêer UDF 816/5(A), inlae 16, Brief van AĠ aan MEF, 11 Mar 1942.

122 MAB : AG (Gp 1), houer 194, lêer AG 736/115/1, Brief van AHGS aan AG, 31 Mar 1944

23 MAB : Narratives and Unfo 24: 14461-14650, p.14557.

124 MAB : MHAD, deel 1 (ontbinde eenhede), Suid-Afrikaanse Inligtingskorps, p.59.

125 MAB : CGS (Gp 2), houer 214, lêer 367/13/10, Inligtingskorps voorlopige oorlogsterkte, 30 Okt 1940.

126 MAB : Narratives and Unfo 24: 14461-14650, pp.14575-14581.

27 MAB : Eenheidsgeskiedenislêer, vol 1, SA Inligtingskorps.

128 MAB : DCS-CGS, houer 65, lêer O(M)1/7, inlae 43, Omsendbrief oor VSP, 14 Feb 1941.

29 MAB: Narratives and Unfo 24: 14461-14650, p.14563.
} 
ritzburg, Piet Retief, Voortrekkerhoogte, Kaapstad, Witwatersrand, Bloemfontein, Barberton, Germiston, Kimberley, Ladysmith, Milnerpark en Premier Myn ontplooi. ${ }^{130}$ VSP-elemente buite die Unie het die Veldsekerheidsvleuel, SA Basis, UVM, MiddeOoste hernoem na 1 (SA) Verbindingslynveldsekerheidseksie, asook 6 Pantser Divisie se 66 Veldsekerheidseksie ingesluit.

Die VSP het die karakter van 'n elite eenheid aangeneem en dit was baie hoog aangeskrewe by die Geallieerde magte. In Italië was die VSP vir die konfiskering van groot getalle onwettige wapentuig, die arrestasie van drosters, saboteurs en valskermspringers en selfs die vernietiging van 'n geheime wapen en ' $n$ gifgasfabriek verantwoordelik. ${ }^{131}$ Die VSP kan beskou word as ' $n$ baie effektiewe stutorgaan van Seksie Ib.

\section{DIE LUGINLIGTING- SKAKELOFFISIER (AILO)}

Die AILOs ("Air Intelligence Liaison Officers") was inligtingskorpslede wat saam met die Lugmag gewerk het. In Desember 1940 was die AlLOs in vier AILO-seksies georganiseer, met een seksie in reserwe. Die AILO-seksie het aanvanklik uit drie offisiere, drie onderoffisiere en twee manskappe bestaan, ${ }^{132}$ maar is teen Februarie 1942 tot drie offisiere, drie stafsersante en drie sersante uitgebrei. ${ }^{133}$ Die AILO moet onderskei word van die lugmaginligtingsoffisier wat met normale lugmaginligtingswerk belas was. Die AILO se taak was om informasie te ruil tussen die Leër en die Lugmag en hy moes hom beywer vir leër-lugmagsamewerking. Die Imperiale magte het gepraat van ' $n$ lugmagskakeloffisier (ALO) maar hy het dieselfde taak verrig as ' $n$ AILO. ${ }^{134}$

Die AILO was meer as net ' $n$ inligtingsoffisier en het dus spesialisopleiding vereis. AlLOs is by die Militêre Kollege opgelei en het onder Subseksie la(v) van Militêre Inligting geresorteer. Kursus 534G van 7 Mei 1940 tot 28 Mei 1940 was die eerste kursus vir AILOs in die Unie. Benewens normale inligtingsopleiding is lesings oor gevegshantering, vliegtuiguitkenning, battaljonwapens, verkenning, gasoorlogvoering, lugfotovertolking en die gebruik van stereoskope aangebied. Kursus 573G was 'n spesialis AILO-kursus en het lugfotografie, lugnaviga- sie, lugverkenning, lugmagorganisasie, meteorologie en lugafweer ingesluit. Baie tyd is aan praktiese opleiding soos nagvlieg en die oplos van navigasieprobleme afgestaan. ${ }^{135}$

Daar is onderskei tussen vier tipes AILOs na gelang van waar hulle gewerk het (vegverkenning, tenkafweer, hoofkwartiere of lugvleuel). Die take van die AILO was primêr om lugverkenning te reël, om vlieëniers na uitvlugte uit te vra, om inligting aan leëreenhede te versprei, om ' $n$ leërsituasiekaart by te hou en om skakeling tussen leër- en lugmagkomponente te bewerkstellig. Die AILO-seksie kon nieinligtingskorpslede, soos artilleriste, akkommodeer (soortgelyk aan die SANW se Mobiele Lugoperasiesentrum (MLOS)). 'n AlLO-seksie het sowat twee motors, ' $n$ kantoorvragmotor en motorfietse ingesluit om hulle taak te vergemaklik. ${ }^{136}$

Teen Februarie 1942 was daar reeds sewe AILOseksies saamgestel, maar nie sonder probleme nie. Die spesialisvaardighede en verlangde temperament van die AlLOs het beteken dat min offisiere vir die taak geskik was. Die AILO moes goed kon werk onder stres en goed met vlieëniers oor die weg kom. ${ }^{137}$ Aanvanklik is probleme ondervind met beheer en administrasie en die kwessie van rang was problematies. Daar is gevind dat ' $n$ AlLO senior genoeg moes wees om effektief te skakel. Die AILO moes ook bevorderingsgeleenthede vir motiveringsdoeleindes gebied word. Die aantal onderoffisiere per AlLO-seksie is te hoog gevind en fotovertolking en opmeting is gesentraliseer om die probleem op te los. ${ }^{138}$ ' $n$ AlLO kon tot leër/lugmagsteunbeheeroffisier of lugstafoffisier bevorder word, waar sy ondervinding van groot waarde was. ${ }^{139}$ Die AILO was dus nie net vir Seksie la nie, maar vir die hele UVM waardevol.

\section{RADIOMEELUISTERING IN DIE UVM}

Die Subseksie la(iv) van Militêre Inligting was vir radiomeeluistering verantwoordelik. ${ }^{140}$ Op 18 September 1941 het die Adjudant-generaal magtiging vir die daarstel van ' $n$ gekombineerde radiomeeluistering- en kriptografiese eenheid verleen. Dit was egter nie die eerste radiomeeluisteringeenheid nie. In September 1940 het It Sherlock ' $n$ Spesiale Radioseksie ("Special Wireless Section" (SWS)) binne die Seinkorps saamgestel. Dié eenheid het in die

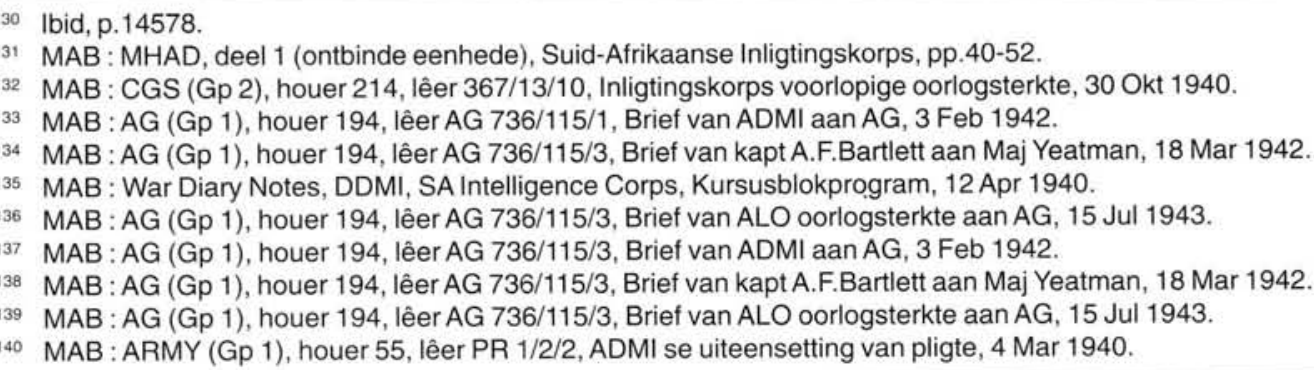


"Noorde" met groot lof gedien. Daar was egter 'n behoefte aan meeluistering binne die Unie en gevolglik is twee lede van die SWS gebruik as kern vir ' $n$ tweede eenheid om binne die Unie te funksioneer. ${ }^{141}$

Die nuwe eenheid het uit " $Y$ " Onderskeppingseenheid en "X" Kriptografiese Seksie bestaan ("Y" was die Imperiaal gestandaardiseerde term vir radioonderskepping). ${ }^{142}$ Elke seksie sou as ' $n$ aparte eenheid funksioneer, elk onder 'n majoor. Die "Y"seksie was onder die administratiewe bevel van die Seinkorps, terwyl "X" onder die ADMI se bevel was. Beide eenhede was onder die operasionele bevel van Militêre Inligting. Die gekombineerde afdeling sou deur 'n luitenant-kolonel aangevoer word, maar die bevelvoerder was klaarblyklik kapt E.R. Cook ("Y"-seksie). Klaarblyklik het die gekombineerde organisasie nie onoorkombare probleme opgelewer nie. ${ }^{143}$

Die onderskeppingseenheid was aanvanklik in ' $n$ huis in Prinsloostraat, Pretoria, gesetel. Die radiomas het bestaan uit drade wat van ' $n$ boom gespan was. ' $n$ Spesiale gebou is later in die watertoringseksie van Voortrekkerhoogte opgerig. Die planne is deur kapt Sherlock opgetrek en het akkommodasie- en ablusiegeriewe ingesluit. Drie radiomaste van meer as 15 meter elk is beplan om wêreldwye ontvangs te verseker. ${ }^{144}$

Die strewe van die eenheid was om die maksimum hoeveelheid bruikbare onderskeppings met die minimum foute te lewer. Goeie samewerking tussen " $X$ " en " $Y$ " was dus nodig. Duitse, Portugese en Franse berigte was van die grootste waarde. Alle seine moes egter onderskep word en outomatiese opnemertoestelle is aangewend. ' $n$ Plaaslik ontwerpte toestel is gebruik om hoë spoed Morsekodeboodskappe op te neem. ${ }^{145}$

Die eenheid, wat aanvanklik uit een offisier en 14 ander range bestaan het, was van ' $n$ hoë standaard. Veral die seiners was bo-gemiddeld in vergelyking met hul kollega's in die Seinkorps. Die meeste van hulle was poskantoortelegrafiste met baie ondervinding. ${ }^{146}$ Die eenheid het ongetwyfeld teen 1943 ' $n$ belangrike bydrae tot Militêre Inligting se insamelingsvermoë gelewer.

\section{OPVOEDINGSOFFISIERE}

Die leëropvoedingskema was ' $n$ uitvloeisel van die verdeelde aard van die Suid-Afrikaanse samelewing. ' $n$ Behoefte het ontstaan om nasionalistiese en Nazi-propaganda teë te werk deur die troepe self ideologies op te voed. Die idee het ontstaan uit ' $n$ memorandum van prof R.F.A. Hoernlé, prof H.J. Rousseau, mnr Leo Marquard en dr E.G. Malherbe wat in 1940 aan generaal Smuts oorhandig is. ${ }^{147}$ Majoor E.G.Malherbe is in bevel van die skema geplaas, onder die vaandel van die Instruksiekorps (Februarie 1941). ${ }^{148}$ Die skema is teen Julie 1943 aan Militêre Inligting oorgedra, ${ }^{149}$ nadat It kol Malherbe die DMI geword het. ${ }^{150}$

Die skema het ' $n$ naamsverandering ondergaan toe die Opvoedingsdiens die Informasiediens geword het. Klaarblyklik het "opvoeding" negatiewe konnotasies gehad. Die troepe moes bewus gemaak word van waarvoor hulle veg - met ander woorde hulle moes ingelig word oor die Unie se kulturele, ekonomiese en politieke hulpbronne. Die troepe moes tydens onaktiewe periodes besig gehou en intellektueel gestimuleer word. Deelname aan die lesings was vrywillig (in soverre optrede in die militêr "vrywillig" kan wees) en die lesings het ' $n$ baie informele karakter aangeneem, wat Geallieerde offisiere verbaas het. Die lesings is klaarblyklik aangenaam ervaar en opvoedingsoffisiere is veral in krygsgevangekampe waardeer. ${ }^{151}$

Opvoedingsoffisiere is by die Militêre Kollege in Pretoria opgelei. Lesings is deur verskeie geleerdes soos professors Wellington, Frankel, Haarhoff, R.F.A. Hoernlé, J.A.I. Agar-Hamilton en pastoor Luckhoff aangebied. Onderwerpe het geografie, sosiologie, geskiedenis, politiek en propagandategnieke sowel as tegniese aspekte, soos aanbiedingstegnieke (of metodologie), ingesluit. Die lesings is deur seminare waar spesifieke onderwerpe logies beredeneer is, opgevolg. Opleiding is ook in die vertoning van films gegee en verskeie films is voorberei. ${ }^{152}$ Personeel van alle range is klaarblyklik by eenhede gewerf en na die voltooiing van hulle opleiding is hulle as opvoedingsoffisiere met die rang van tweede luitenant aangestel. ${ }^{153}$

Die opvoedingsoffiere, wat meestal gegradueerd

\footnotetext{
141 MAB : ARMY (Gp 1), houer 55, Official History of "Y" Signals Section, 17 Feb 1943.

142 F.H. Hinsley: British Intelligence in the Second World War, pp.20-21.

143 MAB : ARMY (Gp 1), houer 55, Official History of " $Y$ " Signals Section, 17 Feb 1943.

144 lbid.

145 Ibid.

146 Ibid.

147 E.G. Malherbe : Never a Dull Moment (Cape Town 1981), p.215.

148 MAB : PAR, lêer P 1/18223, Lt kol E.G. Malherbe.

149 MAB : CGS WAR, bondel 38/6, lêer AG(W)168/2/2/2, Brief van AG aan HGS, 13 Jul 1943.

150 E.G. Malherbe: Never a Dull Moment, p.222.

151 Ibid, pp.216-221.

152 MAB : DCS-CGS, houer 65, lêer O(M)1/7/1, inlae 2, Kursusraamwerk (784G), 18 Mar 1941

153 MAB : DCS-CGS, houer 65, lêer O(M)1/7/1, inlae 6, Omsendbrief van DMT, 29 Apr 1941.
} 
was, is daarna na eenhede uitgeplaas. Aanvanklik is slegs enkele formasies, weens beperkte getalle, van opvoedingsoffisiere voorsien. ${ }^{154}$ Elke hoofkwartier, formasie en eenheid sou uiteindelik 'n opvoedingsoffisier ontvang ( 1 en 2 Divisie). ${ }^{155}$ Die opvoedingsoffisiere het te velde as inligtingsoffisiere opgetree. Sommige is gewond en krygsgevange geneem. Die feit dat opvoedingsoffisiere vir sensuur in hulle eenhede verantwoordelik was, het hulle in staat gestel om moraal te peil en sodoende kon korrektiewe optrede geneem word. Die opvoedingsoffisier het ook verskeie handleidings en nuusblaaie uitgegee. Hulle was populêr en in groot aanvraag by eenheidsbevelvoerders. ${ }^{156}$

Die opvoedingsoffisiere, tesame met ander strukture van Militêre Inligting, het ' $n$ belangrike bydrae tot Militêre Inligting se effektiwiteit gelewer. Die opvoedingsoffisiere kon egter die potensiaal vir politisering verhoog het, omdat hulle taak met dié van die politieke kommissaris in kommunistiese weermagte vergelykbaar was.

\section{PRODUKTE VAN MILITÊRE INLIGTING}

\section{PUBLIKASIES TYDENS DIE OORLOG}

Die belangrikste publikasies van Militêre Inligting was die inligtinghandleidings wat vir die UVM opgestel is. Die UVM het klaarblyklik in 1940 reeds begin om Britse handleidings te herdruk. So is kopieë van die Manual of Military Intelligence in the Field ${ }^{157}$ en die Field Service Pocket Book ${ }^{158}$ deur die Staatsdrukker in Pretoria herdruk. Hierdie handleidings het informasie oor alle aspekte van inligting, sekerheid en sensuur verskaf en het klaarblyklik as grondslag vir die opleiding van UVM-inligtingsoffisiere gedien.

Verskeie publikasies is ook ontwikkel om die verspreiding van inligting te sistematiseer. Die vlootinligtingstaf in Kaapstad het ' $n$ goed georganiseerde stelsel in die vorm van die Cape Area Intelligence Notes en die Cape Area Naval Intelligence Pamphlets gehad. ${ }^{159}$ Militêre Inligting het die Fortnightly Intelligence Report gepubliseer. Die eerste een het op 25 Januarie 1941 verskyn en die laaste een was nommer 49 van 13 Januarie 1944. Die doel van dié rapport was om ' $n$ oorsig rakende militêre, politieke en ekonomiese aspekte op die tuisfront, wat die oorlogspoging kon beïnvloed, te verskaf. ${ }^{160} \mathrm{Be}$ rigte het veral op die "opposisie" en die OssewaBrandwag (OB) gefokus. ${ }^{161}$ Dit kon natuurlik politisering aangehelp het.

' $n$ Dokument van meer inligtingswaarde was die Military Intelligence Pamphlet wat ook op ' $n$ gereelde basis verskyn het. Dié dokument is aan alle eenhede van die UVM versprei en offisiere is aangemoedig om die informasie daarin aan hulle troepe oor te dra. Die dokument het inligting oor internasionale politieke en militêre aangeleenthede bevat en tipiese onderwerpe was "Assault Artillery Attacks", "Improvement of German Defensive Positions" en "The Italian Character". ${ }^{162}$ Die artikels was oor die algemeen nie propagandisties van aard nie en goeie tegniese informasie is oorgedra.

Die belangrikste gereelde inligtingspublikasies blyk te wees die "Militêre Inligtingopsommings" wat dwarsdeur die UVM, insluitende aan ministers en sekretarisse, versprei is. Kopieë is selfs na Londen versend en die dokument blyk van 'n hoë gehalte te wees. ${ }^{163}$

'n Meer propagandistiese dokument was die Ic Digest wat deur Seksie Ic versprei is. Tipiese artikels het ingesluit "The Truth will out" en "America - Democracy's Powerhouse". Die dokument het informasie oor Seksie lc versprei en het veral die leëropvoedingskema bevorder. Uit ' $n$ suiwer inligtingsoogpunt blyk dit egter van min waarde te wees. ${ }^{164}$ Die Seksie Ic-staf te velde het verskeie propagandakoerante soos Jambo, Askari en L'Eco uitgegee. ${ }^{165}$

\section{SPESIFIEKE VERSLAE EN BERIGTE}

Militêre Inligting het nie net inligting (en informasie) deur gereelde publikasies versprei nie. Verskeie dokumente is ook saamgestel om spesifieke behoeftes te bevredig. Militêre Inligting het verskeie produkte op ' $n$ gereelde basis saamgestel wat ' $n$ goeie aanduiding gee van die effektiwiteit van Militêre Inligting se inligtingsproses en van die insamelingsproses wat die informasie opgelewer het.

Die eerste geval was ' $n$ moontlike staatsgreep wat die OB in 1941 sou uitvoer. Ene kapt J.L. van Rens-

154 E.G. Malherbe : Never a Dull Moment, p.217.

155 MAB : DCS-CGS, houer 65, lêer O(M)1/7/1, inlae 6, Omsendbrief van DMT, 29 Apr 1941.

156 E.G. Malherbe: Never a Dull Moment, pp.221-222, 236-238.

157 Manual of Military Intelligence in the Field (Pamphlet No 2-1938), Generale Staf UVM, Okt 1946.

158 Field Service Pocket Book (Pamphlet No 3), Generale Staf UVM, Pretoria, 1940.

159 MAB: DC, houer 3512, lêer DC 17926/11/1, vol II, Cape Area Intelligence Notes, 17 Jun 1941.

160 MAB : DCS-CGS, houer 85, lêer $\mathrm{O}(\mathrm{M}) 30 / 3$, Fortnightly Intelligence Report, No.49.

161 MAB : DCS-CGS, houer 85, lêer O(M)30/3, Fortnightly Intelligence Report, No.35.

162 MAB : DCS-CGS, houer 115, lêer O(M)71/6, Military Intelligence Pamphlet, vol v, no 2, 1 Jan 1944.

163 MAB : CGS (Gp 2), houer 92, lêer O(1)2/2(65), Military "l" Summary (Africa), No.23.

164 MAB : DCS-CGS, houer 65, lêer O(M)1/7/1, Ic Digest, Apr 1941.

165 MAB : ARMY (Gp 1), houer 55, lêer PR 1/2/1, Voorstel vir die herorganisasie van Propaganda- en Publisiteit-seksie, ongedateerd. 
burg, van die VSP, het kovert ' $\mathrm{n}$ OB-vergadering in Middelburg bygewoon. Hy het 'n rapport, getiteld Ossewa Brandwag activities: Middelburg aan Militêre Inligting versend. ' $n$ Goeie opsomming van die gebeure is gelewer, maar die kaptein het gereeld sy eie opinie laat deurskemer. ' $n$ Tema in die rapport was die vermoede dat die OB ' $n$ staatsgreep kon loods. ${ }^{166}$ Op 17 Mei 1941 het ' $n$ inligtingsoffisier (klaarblyklik It A. Mann) ' $n$ flitsberig aan die ADMI (It kol Kreft) geskryf, waarin teen 'n moontlike aanslag op generaal Smuts se lewe gewaarsku is. Die inligting was hoofsaaklik gebaseer op "fluisteringe" en die waarneming van "senuweeagtigheid" onder OB-leiers, gekoppel aan ' $n$ besoek van generaal Smuts. ${ }^{167}$ Die vrees vir ' $n$ staatsgreep was algemeen en 17 of 18 Mei 1941 was die verwagte datum. Die inligting was uit telefoonmeeluistering, gebuite dokumentasie en selfs ' $n$ berig uit Ankara afkomstig. ' $n$ Lys van 500 verdagte OB-lede in die UVM is ook voorberei. ${ }^{168}$ Goeie inligting is dus geproduseer en voorsprongmaatreëls kon geloods word.

In 1942 het die UVM ' $n$ inval in Mosambiek beplan. Die operasie "Z-plan", het die besetting van Mosambiek ten doel gehad. ${ }^{169}$ Goeie inligting sou ' $n$ voorvereiste vir sukses wees. Lt kol H.S. Cilliers, van die beplanningstaf, het op 3 Februarie 1942 'n skrywe aan die ADMI gerig, waarin hy lof vir Militêre Inligting se steun betuig het. Die normale inligtingsopsomming was egter onvoldoende en spesiale reëlings moes getref word om verspreiding aan die beplanningstaf te verseker. Dit blyk dat daar baie goeie samewerking tussen Militêre Inligting en die beplanningstaf was. ${ }^{170}$

'n Dokument van ' $\mathrm{n}$ laer kwaliteit was die Notes on German and Italian Tanks wat op 28 Oktober 1940 deur Seksie la aangebied is. Dit het uit ' $n$ beskrywing van Duitse taktiek bestaan, tesame met tegniese data oor Duitse wapentuig. Die tenks is in lig, medium, swaar (70 ton) en superswaar (120 ton!) kategorieë verdeel. ${ }^{171}$ Die swaarste Duitse tenk in 1940 was egter die Pzkw IV (24 ton), terwyl die swaarste operasionele tenk van die oorlog, die Jagdtiger, net 70.5 ton geweeg het. ${ }^{172}$ Die kern van Duitse taktiek is gesien as die kombinasie van ligte en swaar tenks (kategorieë wat nie bestaan het nie) in omvleuelingsaksies, ondersteun deur lugkrag. Diep penetrasie en die vermyding van weerstand, wat fundamenteel was tot Duitse taktiek, is nie genoem nie. Daar word ook beweer dat Duitse en Italiaanse taktiek soortgelyk was, en melding word gemaak van (fiktiewe) vlamwerperstelsels. ${ }^{173}$ Ter verdediging kan aangevoer word dat die informasie tweedehands moes gewees het, omdat die UVM nog nie in 1940 kontak met Duitse magte gehad het nie.

Die DMI, It kol E.G. Malherbe, het ook ' $n$ wakende oog oor die Afrikanerbroederbond (AB) gehou. Daar is minstens sedert 1943 insameling op AB-vergaderings gedoen en baie lede is geïdentifiseer. In Maart 1944 het die DMI ' $n$ verslag van 25 bladsye oor die $A B$ aan generaal Smuts oorhandig. Die gevolgtrekkings, wat sterk bewoord was, het die AB as ' $n$ gevaarlike bron van subversie in die land verbeeld. Ten spyte van die DMI se aanbevelings het generaal Smuts geen optrede teen die $A B$ geloods nie, klaarblyklik ter wille van versoening. ${ }^{174}$ Die verslag het egter ' $n$ belangrike bron vir latere skrywers oor die AB geword. Die feit dat geen gehoor aan die $D M l$ se waarskuwings gegee is nie, is nie ' $n$ uitsondering in die inligtingswêreld nie en dit moet gesien word teen die agtergrond van ' $n$ Militêre Inligtingafdeling wat in ' $n$ hoogs verpolitiseerde omgewing moes funksioneer.

\section{SLOT}

\section{OPSOMMING}

Tydens die stigting van die UVM in 1912 is nie voorsiening gemaak vir 'n militêre inligtingsvermoë nie. Tydens die Eerste Wêreldoorlog is verskeie sogenaamde inligtingseenhede op die been gebring en 'n Militêre Inligtingsfunksie is in die Generale Staf gevestig. Ná die oorlog het dié funksie 'n geleidelike afname getoon, totdat dit een van verskeie take van spesifieke stafposte geword het. Die inligtingsfunksie is deur ' $n$ gebrek aan fondse en ' $n$ tekort aan interdepartementele samewerking gekenmerk. Teen 1937 het ' $n$ hernude belangstelling in inligting gelei tot die aanstelling van It kol B.W. Thwaites as die hoof van Militêre Inligting. Sy taak is bemoeilik deur ' $n$ gebrek aan ondervinding, kennis, voorbereidende werk in die UVM en die feit dat sy aanstelling (deeltyds) slegs een werksdag elke twee weke toegelaat het. Sy besoek aan die Britse Militêre Inligtingsorganisasie het vrugte afgewerp en geleidelik is ' $n$ inligtingsorganisasie gevestig. Baie van sy voorstelle is egter afgekeur en teen September 1939 het Militêre Inligting slegs uit drie offisiere bestaan.

\footnotetext{
166 MAB : DCS-CGS, houer 85, lêer O(M)31, Verslag van kapt J.L.van Rensburg aan ADMI, 13 Mei 1941.

167 MAB : DCS-CGS, houer 85, lêer O(M)31, Flitsberig aan It kol Kreft, 17 Mei 1941.

168 MAB : DCS-CGS, houer 85, lêer O(M)31, Veiligheidsopsomming vir HGS, 30 Apr 1941.

169 MAB : DCS-CGS, houer 5, lêer O(M)SP 1, Synopsis of Plan, 18 Jul 1941.

170 MAB : DCS-CGS, houer 5, lêer O(M)SP 1, Brief van Militêre Kollege aan HGS, 3 Feb 1942.

171 MAB : CGS (Gp 2), houer 94, lêer 169/13, Notas oor Duitse en Italiaanse tenks, 28 Okt 1940.

172 K. Maksey: Tank versus Tank (London 1988), pp.99, 139.

173 MAB : CGS (Gp 2), houer 94, lêer 169/13, Notas oor Duitse en Italiaanse tenks, 28 Okt 1940.

174 D. Harrison: The White Tribe of South Africa (Cape Town 1981), pp.136-141.
} 
Ná die uitbreek van die Tweede Wêreldoorlog is Militêre Inligting met vier offisiere op 'n oorlogsgrondslag geplaas. Inligtingsoffisiere is by die Militêre Kollege opgelei en geld en magtiging is verkry om agente te werf. Die Militêre inligtingsorganisasie is in twee verdeel deur ' $n$ Direkteur van Inligting (Burgerlike Sekerheid) en ' $n$ Adjunkdirekteur van Militêre Inligting (Militêre Inligting) aan te stel. Hierdie organisasie en rolverdeling was onbevredigend en baie probleme het ontstaan. ' $n$ Gebrek aan inter-departementele samewerking was die grootste probleem en ' $n$ departementele komitee en ' $n$ Verdedigingsadvieskomitee het die saak ondersoek. Hulle aanbevelings het gelei tot die daarstel van die "Intelligence Clearance Bureau" (later die "Intelligence Records Bureau") onder kol H.J. Lenton. Die Direkteur van Inligting se organisasie is ontbind en slegs die ADMI-organisasie (It kol H.T. Newman) het bly voortbestaan. Die ADMI het intussen ' $n$ inligtingskorps vir die MFF begin ontwikkel. Dié het gegroei uit 'n "skadustruktuur" genaamd Seksie Ix binne Militêre Inligting. Die groot probleem was 'n gebrek aan inligtingsoffisiere met konvensionele ondervinding. Die Inligtingskorps sou ' $\mathrm{n}$ belangrike bydrae tot die MFF se inligtingsvermoë lewer, ten spyte van konflik tussen die UVM-inligtingskorps en die Oos-Afrika-inligtingskorps.

Teen 1943 was Militêre Inligting 'n direktoraat gelykstaande aan die Direktoraat Operasies. Die DMI was vir alle militêre inligtingsaktiwiteite asook die UVM-filmeenheid, die Oorlogsmuseum en die Leëropvoedingskema verantwoordelik. Die DMI se staf was in drie seksies verdeel. Seksie la (Informasie) was vir die verwerking en verspreiding van inligting verantwoordelik. Die seksie het bestaan uit vyf subseksies wat vir vyandelike oogmerke en operasies, die daarstel van ' $n$ slagorde, vyandelike infrastruktuur en die monitor van vyandelike radioberigte verantwoordelik was. Seksie lb (Sekerheid) was vir die insameling deur spesialismetodes en vir militêre sekerheid verantwoordelik. Die subseksies was vir spesialisinsameling, en burgerlike- en militêre inligting (sekerheidsgerig) verantwoordelik. Seksie Ic (Sensuur) was in vyf subseksies verdeel en was verantwoordelik vir militêre sensuur, publisiteit, propaganda en kriptografie. Die verskillende komponente van die UVM se militêre inligtingsvermoë het aan die toepaslike seksies van Militêre Inligting gerapporteer.

Die Inligtingskorps was die belangrikste komponent en het die meeste ander komponente omvat. Die Korps het gegroei uit die MFF se inligtingskorps en alle inligtingspersoneel was teen 1943 lid van dié korps. Die kommandant of "korpsdirekteur" het die belange van al die spesialisrigtings en personeel behartig (spesifiek organisering, opleiding, toewysing en bevordering).

Die Veldsekerheidspolisie (VSP) het as uitvoerende been van Seksie lb se sekerheidstruktuur gefunksioneer. Die VSP het baie gedesentraliseerd gefunksioneer en elemente is by alle eenhede en formasies in die Unie en te velde ontplooi.

Die Luginligtingskakeloffisiere (AILO) het as inligtingselemente saam met Lugmageenhede geopereer. Hulle was hoogs gespesialiseerd en het ' $n$ waardevolle bydrae tot Seksie la se funksionering gelewer.

Radiomeeluistering in die Unie was die verantwoordelikheid van ' $n$ gekombineerde eenheid onder die vaandel van subseksie la(iv). Die "Y"-seksie het uit Voortrekkerhoogte geopereer en seine van regoor die wêreld kon onderskep word.

' $n$ Leëropvoedingskema was teen 1943 ook die verantwoordelikheid van Militêre Inligting. Opvoedingsoffisiere moes vyandelike propaganda in die UVM deur middel van ideologiese opvoeding teëstaan. Hulle het klaarblyklik goeie werk gelewer, maar het die moontlikheid van verpolitisering in Militêre Inligting geskep.

Militêre Inligting het verskeie gereelde publikasies gelewer. Britse Inligtingshandleidings is reeds in 1940 in die Unie herdruk. Verspreiding is gesistematiseer deur verskeie gereelde produkte van die Vloot, die Fortnightly Intelligence Report (binnelandse aspekte), die Military Intelligence Pamphlet (algemene inligtingstema's) en die Militêre Inligtingopsommings, wat van hoë gehalte was. Propagandistiese publikasies van Seksie Ic het die Ic Digest, Jambo, Askari en L'Eco ingesluit. Produkte is ook op ' $n$ ongereelde basis saamgestel om spesifieke behoeftes te bevredig. So het Militêre Inligting ' $n$ goeie inligtingsprentjie oor ' $n$ moontlike OB-staatsgreep in 1941 opgebou. Militêre Inligting het goed met die beplanningstaf van die "Z"-plan saamgewerk. ' $n$ Baie swak dokument oor vyandelike pantsermagte is in 1940 opgestel. Talle foute is begaan, wat moontlik aan inligtingspersoneel buite die UVM toegeskryf kan word. Die DMI het ook 'n dokument oor die Afrikanerbroederbond saamgestel, waarin optrede teen die $\mathrm{AB}$ aanbeveel is. Politieke faktore kon moontlik tot die ignorering van die DMI se waarskuwings in hierdie verband gelei het.

\section{GEVOLGTREKKINGS}

Die UVM het in die periode $1937-1943$ byna uit niks ' $n$ militêre inligtingsorganisasie ontwikkel. Die ontwikkelingsproses was primêr kol B.W. Thwaites se verantwoordelikheid. In 1943 het die inligtingsorganisasie verskeie spesialisrigtings en -funksies omvat wat aan die veelvuldige behoeftes van die UVM moes voldoen, maar hoe effektief was dié organisasie?

Daar was verskeie swakhede wat met kol Thwaites 
se bevelsoorname gepaard gegaan het. Geen databasisse en -strukture het bestaan nie, maar tog was die tekort aan mense met inligtingsondervinding meer krities. Kol Thwaites se deeltydse aanstelling was ook onvoldoende. Die feit dat die Britte ' $n$ vertrouens-probleem met die Unie gehad het, kon ' $n$ ernstige swakheid gewees het. Kol Thwaites se onvermoë om konsepvoorstelle aanvaar te kry, kon op " $n$ vredestydse "anti-inligting"-mentaliteit in die Generale Staf dui. Teen September 1939 was goeie vordering egter gemaak.

Die ontwikkeling van Militêre Inligting in 1939 tot 1940 weerspieël ' $n$ dieper swakheid. Militêre Inligting se fokus was primêr op die sekerheids- en teeninligtinggebied, wat op sigself die inligtingsfunksie benadeel het. Militêre Inligting het ook oortree op die gebied van binnelandse veiligheid. Insameling is op politieke figure en ander liggame gedoen. Die skeiding van die funksie binnelandse veiligheid (Direkteur Inligting) en die militêre inligtingsfunksie (ADMI) was slegs ' $n$ tydelike oplossing. Die hervorminge van Oktober 1940 was ook klaarblyklik gerig op beter interdepartementele samewerking en nie soseer die "suiwering" van die militêre inligtingsfunksie nie. Die besondere swakheid moet egter toegeskryf word aan die verdeelde aard van die politiek in die Unie wat skeiding tussen burgerlike en militêre inligting bemoeilik het.

Die ontwikkeling van die MFF se inligtingsfunksie het ' $n$ probleem ontbloot wat die gevolg was van die situasie bespreek in die vorige paragraaf. Daar was ' $n$ ernstige tekort aan inligtingsoffisiere wat ondervinding in konvensionele operasies gehad het. Die meeste inligtingsoffisiere se ondervinding was op die gebied van sekerheid en teeninligting. Die probleem is klaarblyklik teen 1943 oorkom toe baie inligtingsoffisiere te velde ontplooi is.

Die organisasie van Militêre Inligting dui op nog ' $n$ swakheid. Seksie Ic se aktiwiteite is moeilik met die lynfunksie van ' $n$ militêre inligtingsorganisasie versoenbaar. Praktiese oorwegings kon wel die sensuurfunksie in Militêre Inligting genoodsaak het en propaganda-aktiwiteite word normaalweg saam met inligting gegroepeer. Dit verlaag egter die geloofwaardigheid van so 'n militêre inligtingsorganisasie en lei tot wantroue jeens inligtingsoffisiere. Die feit dat propaganda op die tuisfront gefokus was, het ruimte vir politisering gelaat. Die probleem kan weereens na die politieke verdeeldheid in die Unie teruggespoor word.

Die totstandkoming van ' $n$ inligtingskorps was ' $n$ baie positiewe ontwikkeling. Goeie spesialisvaardighede in die vorm van die VSP, AILO's en radiomeeluisteringseenhede het ' $n$ belangrike bydrae tot die militêre inligtingsfunksie gelewer. Die opvoedingsoffisiere was ' $n$ ander saak. Ideologiese skoling behoort nooit deel van ' $n$ militêre inligtingsfunksie te wees nie, trouens dit hoort hoegenaamd nie in ' $n$ weermag tuis nie. Te veel ruimte vir verpolitisering kan deur sulke aktiwiteite geskep word. Dit is nogmaals ' $n$ probleem wat na die politieke situasie in die Unie teruggespoor kan word.

Die enkele produkte wat bespreek is, reflekteer die swakpunte van die organisasie. Goeie sekerheidsinligting is geproduseer (OB-verslag). Die inligtingsproduk wat behandel is (Tenkverslag) reflekteer onvoldoende militêre inligting. Die produkte is egter te selektief om werklik gevolgtrekkings te maak. Inligtingsverspreiding was wel goed georganiseer met die gereelde publikasies en verslae.

Met inagneming van die kort ontwikkelingsperiode (1937-1943), die omgewing (polities) waarin Militêre Inligting moes ontwikkel en die inherente swakhede wat daaruit voortgevloei het, kan tot die gevolgtrekking gekom word dat die ontwikkelingsproses wel geslaagd was. " $n$ Inligtingsorganisasie wat die behoeftes van die tyd in ' $n$ redelike mate bevredig het, is ontwikkel.

Die groeipyne van die UVM se Militêre Inligtingsorganisasie bewys dat ' $n$ inligtingsorganisasie nie oornag uit niks geskep kan word nie. So 'n ontwikkelingsproses gaan met baie probleme, foute en kostes gepaard wat geen moderne weermag kan bekostig nie. ' $n$ Tekort aan professionele inligtingsoffisiere kan ook die proses van verpolitisering verhoog, wat geen moderne staat kan bekostig nie. ' $n$ Inligtingsorganisasie is nie ' $n$ kraan wat oop en toe gedraai kan word na gelang van moontlike bedreigings nie. 